(II) Nordiska ministerrådet

Norden som en gemensam marknad för människohandel 

Norden som en gemensam marknad för människohandel

TemaNord 2018:501 


\title{
Norden som en gemensam marknad för människohandel
}

\author{
ISBN 978-92-893-5331-1 (PRINT) \\ ISBN 978-92-893-5332-8 (PDF) \\ ISBN 978-92-893-5333-5 (EPUB) \\ http://dx.doi.org/10.6027/TN2018-501 \\ TemaNord 2018:501 \\ ISSN $0908-6692$
}

Standard: PDF/UA-1

ISO 14289-1

(c) Nordic Council of Ministers 2018

Photos: Laura Mendelin

Print: Rosendahls

Printed in Denmark

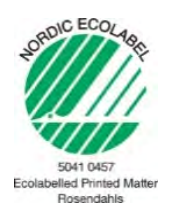

\section{Disclaimer}

This publication was funded by the Nordic Council of Ministers. However, the content does not necessarily reflect the Nordic Council of Ministers' views, opinions, attitudes or recommendations.

\section{Rights and permissions}

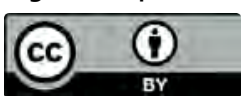

This work is made available under the Creative Commons Attribution 4.0 International license (CC BY 4.0) https://creativecommons.org/licenses/by/4.0

Translations: If you translate this work, please include the following disclaimer: This translation was not produced by the Nordic Council of Ministers and should not be construed as official. The Nordic Council of Ministers cannot be held responsible for the translation or any errors in it.

Adaptations: If you adapt this work, please include the following disclaimer along with the attribution: This is an adaptation of an original work by the Nordic Council of Ministers. Responsibility for the views and opinions expressed in the adaptation rests solely with its author(s). The views and opinions in this adaptation have not been approved by the Nordic Council of Ministers.

Third-party content: The Nordic Council of Ministers does not necessarily own every single part of this work. The Nordic Council of Ministers cannot, therefore, guarantee that the reuse of third-party content does not infringe the copyright of the third party. If you wish to reuse any third-party content, you bear the risks associated with any such rights violations. You are responsible for determining whether there is a need to obtain permission for the use of third-party content, and if so, for obtaining the relevant permission from the copyright holder. Examples of third-party content may include, but are not limited to, tables, figures or images. 
Photo rights (further permission required for reuse):

Any queries regarding rights and licences should be addressed to:

Nordic Council of Ministers/Publication Unit

Ved Stranden 18

DK-1061 Copenhagen K

Denmark

Phone +4533960200

pub@norden.org

\section{Nordic co-operation}

Nordic co-operation is one of the world's most extensive forms of regional collaboration, involving Denmark, Finland, Iceland, Norway, Sweden, and the Faroe Islands, Greenland and Åland.

Nordic co-operation has firm traditions in politics, economics and culture and plays an important role in European and international forums. The Nordic community strives for a strong Nordic Region in a strong Europe.

Nordic co-operation promotes regional interests and values in a global world. The values shared by the Nordic countries help make the region one of the most innovative and competitive in the world.

The Nordic Council of Ministers

Nordens Hus

Ved Stranden 18

DK-1061 Copenhagen K, Denmark

Tel.: +453396 o200 www.norden.org

Download Nordic publications at www.norden.org/nordpub 



\section{Innehåll}

Sammanfattning . .7

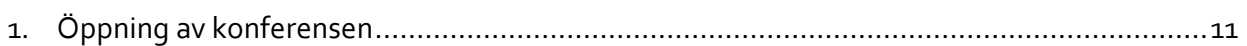

2. Tema: Barn som offer för människohandel .........................................................15

$2.1 \quad$ Nya former av människohandel i dagens Europa ..............................................15

2.2 Barn, flyktingar och människohandel ...........................................................

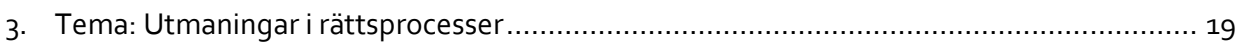

3.1 Identifiering av offer för människohandel ....................................................... 22

3.2 Människohandel och utmaningar i polisutredningar ..................................... 25

4. Tema: Kvinnor och män som offer för människohandel............................................ 29

4.1 Psykiska konsekvenser av sexuellt utnyttjande och rättsprocessen .......................29

4.2 Får offren - både kvinnor och män - den hjälp de behöver? ..............................

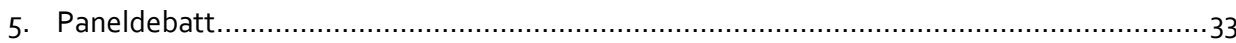

5.1 Hur kan Norden samarbeta i insatsen mot människohandel? ............................... 33

5.2 Sammanställning av paneldebatten ............................................................

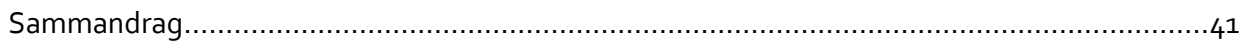

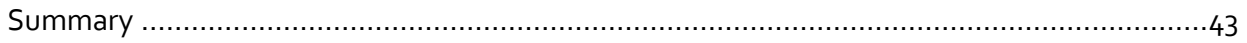





\section{Sammanfattning}

Den nordiska konferensen Norden som en gemensam marknad för människohandel arrangerades den 26.10.2016 i Helsingfors, Finland.

På konferensen diskuterades de nordiska ländernas gemensamma utmaningar i att bekämpa människohandel. Målet med konferensen var att utbyta erfarenheter om nya trender inom människohandel, barn som offer för människohandel, rättsprocessen från identifiering av offren till domstolsbeslut, identifiering av och hjälp till offer. Ett jämställdhets- och könsperspektiv hade inarbetats i hela konferensprogrammet, genom att alla föreläsare hade getts i uppgift att i sina presentationer reflektera över hur människohandel påverkar kvinnor och män, flickor och pojkar.

Nya former inom människohandel idag utnyttjar kvinnor och män, flickor och pojkar genom att tvinga dem till att utföra kriminella handlingar, arbeta inom olika branscher och sälja sexuella tjänster. Människohandlarna lockar dessa människor med löften om arbete och bostad, att resa till Norden från andra delar av Europa. Människohandlarna använder även offrens identiteter för bidragsfusk genom att utnyttja de nordiska ländernas välfärdssystem. Offren är oftast inte medvetna om att de utnyttjas i kriminella handlingar.

En av utmaningarna i bekämpning av människohandel idag i de nordiska länderna är att människohandlarna ser Norden som en gemensam marknad, och sänder offren från ett land till ett annat. Detta ger stora utmaningar för brottsutredarna eftersom lagstiftningen är nationell och brotten är gränsöverskridande, när samma människohandlare opererar samtidigt i de olika nordiska länderna. Detta betyder att det finns ett ökat behov för samarbete mellan myndigheter och organisationer för att effektivera insatserna och brottsbekämpningen mot människohandeln.

Konferensen hade som utgångspunkt de resultat och erfarenheter, som Nordiska ministerrådet och organisationer i de nordiska länderna har erhållit, inom de gemensamma nordiska projekten. Idag finns det i Norden många rapporter, analyser och rekommendationer om åtgärder för bekämpning av människohandel, som baserar sig på erfarenheterna från nationella aktiviteter.

Konferensen diskuterade tre temahelheter och avslutades med en paneldebatt:

- Barn som offer för människohandel.

- Utmaningar i rättsprocessen.

- Kvinnor och män som offer för människohandel.

- Paneldiskussion: Hur kan Norden samarbeta i insatsen mot människohandel? 
Under konferensen diskuterades frågeställningar som:

- Hurudana nya former av människohandel uppdagas i Norden och Europa?

- Vilka utmaningar möter polis och åklagare idag i processen vid utredningar av olika former av människohandel?

- Hur utnyttjas barn som är offer för människohandel och hur hanteras fallen?

- Hur utnyttjas kvinnor och män i människohandel?

- Varför är människohandel för sexuellt utnyttjande en jämställdhetsfråga?

- Vilka metoder använder förövaren för att få makt över sina offer?

- Vilka är de psykiska konsekvenserna av människohandeln?

- Hur kan man bäst utbyta erfarenheter, arbetsmetoder och kunskap?

- Hur kunde samarbetet i gränsöverskridande utredningar se ut i praktiken?

- Vad kan uppnås genom ett nordiskt samarbete?

Konferensen samlade 160 deltagare från alla nordiska länder. Utav dessa var 37 poliser och 32 åklagare, domare och advokater, d.v.s. totalt $43 \%$ representerade polis- och rättsväsendet. Andra deltagare var tjänstemän, experter, forskare och representanter för medborgarorganisationer.

Konferensen arrangerades av diskrimineringsombudsmannen i Finland, som även verkar som Finlands nationella rapportör om människohandel, i samarbete med det finska ordförandeskapet i Nordiska ministerrådet. Konferensen finansierades av Nordiska ministerrådet och i finansieringen deltog MR-JÄM, MR-LAG och NORDBUK.

Presentationer från konferensen Norden som en gemensam marknad för människohandel kan läsas via linken:

https://www.syrjinta.fi/sv/web/sv/-/nordisk-konferens-norden-som-gemensam-

marknad-for-manniskohandel 


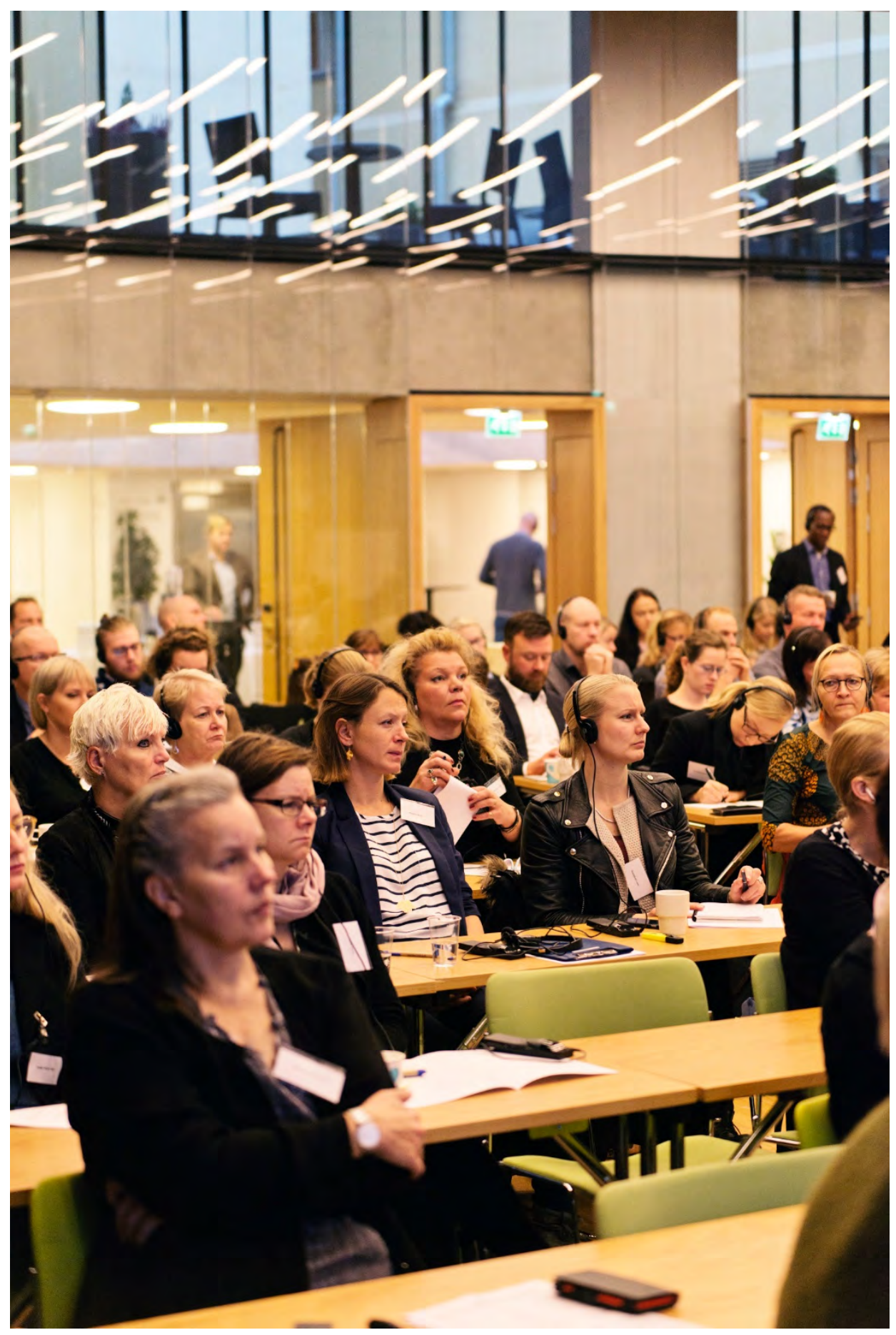





\section{1. Öppning av konferensen}

- Moderator: Venla Roth, överinspektör, Diskrimineringsombudets byrå, Finland.

Diskrimineringsombudsman Kirsi Pimiä, Finlands nationella rapportör om människohandel, öppnade konferensen med att säga att konferensen erbjuder deltagarna ett forum för att utbyta erfarenheter om utmaningar i att bekämpa människohandel. Konferensen ska även öka förståelsen och kunskapen om människohandel och komma med förslag för åtgärder för att lösa gemensamma utmaningar. Konferensen ska diskutera nya utmaningar som idag inte tillräckligt bra identifieras i Norden. Detta är bl.a. människohandel där barn och fullvuxna tvingas till kriminella handlingar.

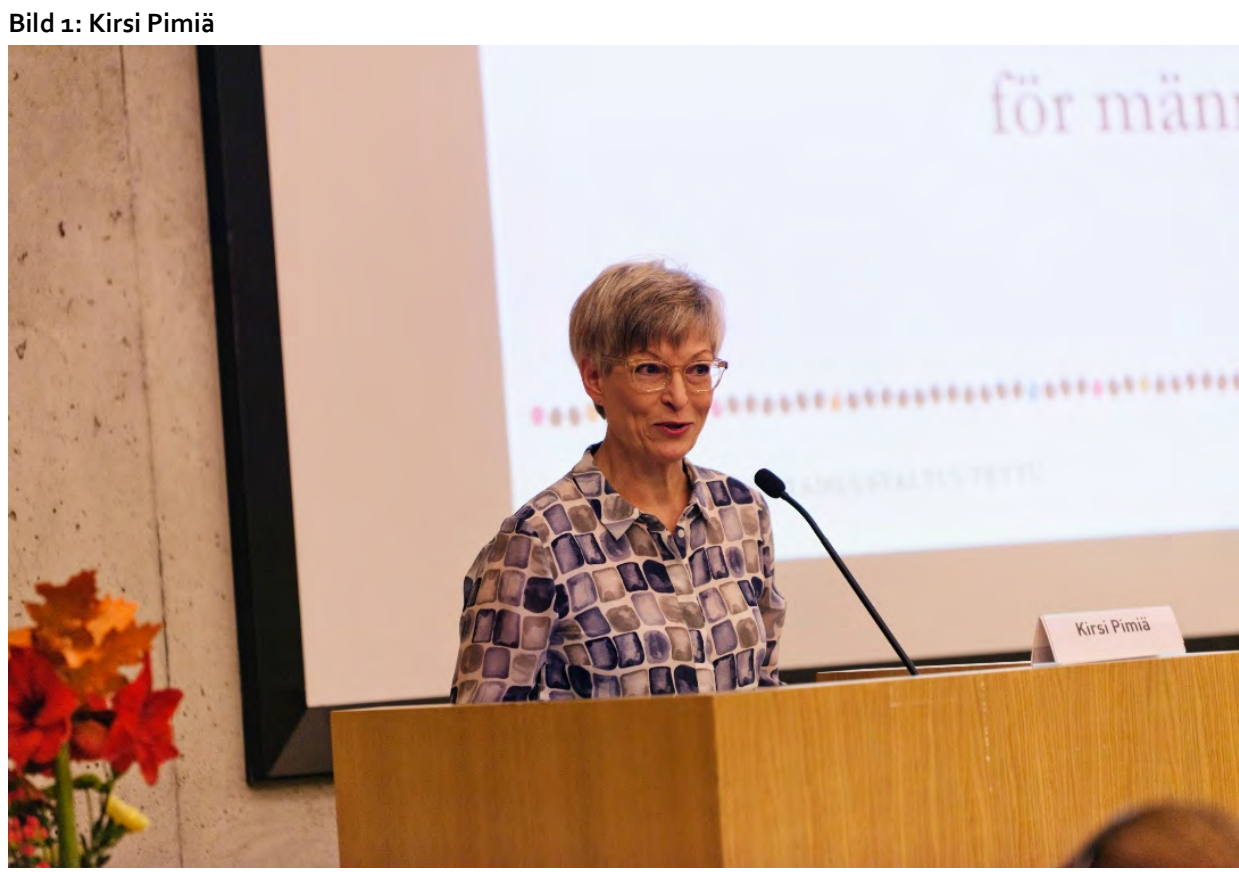

Den nationella människohandelsrapportören i Finland är en självständig, obunden myndighet som ska övervaka och främja insatser mot människohandel, genom att samla in och analysera kunskap, rapportera och ge konkreta förslag till ändringar i lagstiftning och metoder att effektivare upptäcka människohandel.

För sju år sedan då den nationella människohandelsrapportören startade sitt arbete fanns det få polisutredningar och domar om människohandel och endast ett litet antal offer fick hjälp och systemets rättskydd var svagt. Trots många utmaningar har Finland och de andra nordiska länderna under dessa sju år genom ett medvetet arbete erhållit 
resultat både i bättre identifiering av offren för människohandel och i utveckling av rättsprocesser.

Det är viktigt att diskutera hur man kunde förbättra brottsutredningarna om människohandel. Idag anses att samarbete mellan polis, hjälpsystemet, medborgarorganisationer och social- och arbetsskyddsmyndigheterna är en förutsättning för en lyckad förundersökning och för att garantera offrets rättigheter. I brott om människohandel för sexuellt utnyttjande tar man i dag i beaktande de konsekvenser det sexuella utnyttjandet har haft för offren, som psykiska trauman, och att de bl.a. påverkar offrets deltagande i rättsprocessen. I Finland varierar kvaliteten på förundersökningarna i brottsundersökningarna beroende på i vilken del av landet den genomförs. Detta beror på att man inte kan identifiera eller har kunskap om människohandel. Det räcker inte enbart att kunna identifiera människohandel utan det behövs både resurser och kunskap. I de länder där man betonar människohandeln som gränsöverskridande aktivitet har det grundats specialenheter inom polisen för att stöda förundersökningarna så att inte enskilda poliser behöver arbeta isolerat. Den nationella rapportören i Finland har föreslagit att polisen i Finland skulle diskutera inrättandet av en specialenhet för att utreda människohandelsfall för att få en grupp inom polisen som effektivare kunde bekämpa människohandelsbrott. Den nationella rapportören anser att polisen borde utarbeta en strategi för bekämpning av människohandel för att stärka arbetet med förhandsundersökning av människohandel. Vad borde göras för att förundersökningsmyndigheterna skulle bli bättre på att identifiera människohandel, känna till offrens rättigheter, ha förmågan att skapa en förtrolig stämning, så att offren vågar berätta om sina erfarenheter? Hur ska man avslöja människohandel, speciellt nu när det antas att de papperslösas antal kommer att stiga på grund av förändringar i lagstiftningen?

Kirsi Pimiä poängterade att bekämpningen av människohandel kan inte enbart grundas på enskilda experters arbete. För att få hållbara resultat måste strukturerna och ledningen stöda de enskilda experternas arbete gällande lagstiftning, strategier och planering. År 2015 har speciellt nya former av människohandel upptäckts såsom skenäktenskap (sham marriage) och användning av människohandelsoffer för kriminella handlingar såsom stölder och försäljning av droger. Detta betyder att experter som arbetar med människohandel behöver utbildning om dessa nya fenomen för att effektivt kunna bekämpa människohandel.

Säkerhets- och flyktingkriser, nationalismens spridning, ifrågasättandet av människorättigheter, och populisternas frammarsch under det senaste året påverkar även insatserna mot människohandel. Det är därför viktigt att arbeta utifrån ett människorättsperspektiv och följa de internationella konventionerna och skyldigheterna de nordiska länderna har förbundit sig till och ta detta som utgångspunkt för bekämpning av människohandelsbrott.

Offren för människohandel lever i utkanten av samhället, och de är inte starka på att värna om sina rättigheter. Staterna måste bygga upp aktiva insatser för att identifiera, hjälpa och skydda människohandelns offer. Pimiä avslutade med att säga: "Mänskliga rättigheter hör till alla, oberoende vem vi är eller varifrån vi kommer. 
Demokratiska rättsstaters grundsten är de mänskliga rättigheterna och det är inte till nytta för någon att de smulas sönder. Ett jämställt samhälle, som hedrar alla är möjligt och slutligen vårt eget val."

Inrikesminister Paula Risikko, Inrikesministeriet, Finland, centrala budskap var att man ska skapa ett brett tvärsektorsamarbete för att på ett effektivt sätt kunna utreda människohandelsbrott och identifiera och hjälpa offer för människohandel. Finlands regering presenterade $\mathrm{i}$ oktober 2016 en ny handlingsplan för insatser för människohandel. Teman för detta seminarium finns också i den finska handlingsplanen, som effektivering av arbetet med att identifiera och hjälpa offren för människohandel och barnperspektiv på människohandel. Minister Risikko sade att finska myndigheter, som den ministeriella koordineringsgruppen, den nationella människohandelsrapportören, polisen, offrens hjälpsystem, och medborgarorganisationer utför ett exemplariskt och effektivt samarbete i sina insatser mot människohandel runt om i Finland. Den stora flyktingströmmen till Norden under de senaste åren har resulterat $i$ att Joutseno mottagningscenter, som koordinerar det nationella hjälpsystemet för offren för människohandel i Finland, har mottagit flera offer än tidigare - offrens antal har fördubblats jämfört med tidigare år. Experterna, som arbetar med hjälpsystemet, samarbetar med de andra nordiska länderna och inom olika nordiska nätverk med att utbyta erfarenheter om hur man på bästa sätt kan hjälpa offren både psykiskt och fysiskt. En ökning av identifiering av offren är också ett resultat av insatserna och det målmedvetna arbetet mot människohandel. och det har lett till att man i Finland idag identifierar offer för olika former av människohandel inte bara för tvångsarbete.

Bild 2: Paula Risikko

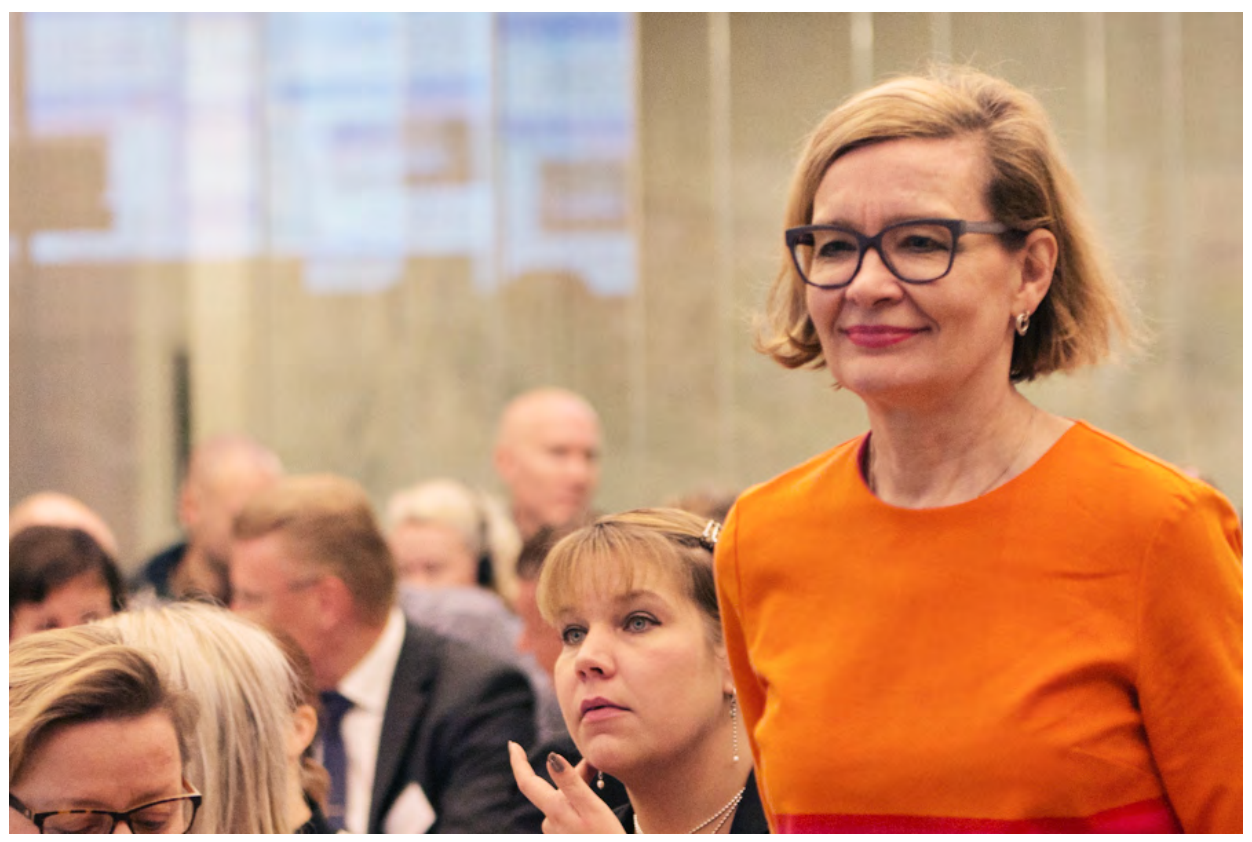


Minister Risikko poängterade också att det är viktigt att skapa fora som denna konferens, där experter från de nordiska länderna kan gemensamt diskutera och utbyta erfarenheter om hur bekämpa människohandel och hur gemensamma nordiska insatser kunde förbättras för att effektivera arbetet mot människohandel. Hon avslutade sitt tal med att tacka finska myndigheter och medborgarorganisationer för det målmedvetna samarbetet om utförs på gräsrotsnivå - nära de människor som blir offer för människohandel. 


\section{Tema: Barn som offer för människohandel}

- Moderator: Terhi Tafari, inspektör, Hjälpsystemet för människohandelsoffer, Finland.

\subsection{Nya former av människohandel i dagens Europa}

Åklagare RudolfChristofferesen, Eurojust, Haag, Holland, inledde med att säga att inget land kan vara stolt över sina insatser mot människohandel, eftersom det idag finns alltför få domar över brott mot människohandel i Europa.

Christoffersen beskrev den ändrade kriminalitetsbilden i Europa idag och sade att det beror på att själva kriminaliteten överskrider nationsgränserna, medan straffsystemen för brott är nationella. Detta leder till att det internationella samarbetet blir allt viktigare. Ett problem för Norden är att de nordiska ländernas välfärdssystem med sociala bidrag är lätt att utnyttja och för att människohandlarna ser Norden som en enda marknad och flyttar offren från ett nordiskt land till ett annat för att utnyttjas på olika sätt. Internet har ändrat vår värld, och det har blivit en kriminalitetsarena med cyberattacks, övergrepp, ID-stölder och olika former av bedrägeri. Detta har medfört nya utmaningar för poliser och åklagare. Brotten utförs i ett land och bevisen finns i ett annat land. Bevismaterial måste översättas från ett språk till ett annat, vilket är dyrt och tidskrävande. Ibland har brotten andra former än dem vi är vana vid. Länderna har även olika processregler för insamling av bevis och detta sker enligt regelverk och processer som alla involverade parter inte alltid har kunskap om.

Idag ses nya former av människohandel i Europa. De kriminella utnyttjar barn och sårbara människor för sexuellt utnyttjande och prostitution och tvingar dem att utföra kriminella handlingar, som butikssnatterier och fickstölder. Prostitution och olika former av sexuellt utnyttjande är den mest vanliga formen av människohandel i Europa, med total $69 \%$ av alla identifierade offer. Christoffersen beskrev ett norskt fall där en 65-årig man i Bergen medverkade i en våldtäkt av barn i Filippinerna via "live streaming". Europol har sagt att denna form av kriminalitet är en väl etablerad realitet. Personer, kan sitta i sitt eget vardagsrum och via internet se hur barn utnyttjas sexuellt. Dessa kan även påverka utnyttjandet genom att de kan ge instruktioner om hur barnen ska utnyttjas i enlighet med deras egna sexuella preferenser. Personer behöver inte mer resa till Asien för att utnyttja barn sexuellt. Det är fattiga barn som utnyttjas genom bl.a. kidnappning, men föräldrar säljer också sina egna barn eftersom profiten är så hög. I Europa finns det tyvärr länder som har hål i sin lagstiftning och som inte har förbjudit streaming. En norsk man kan dömas i Norge för att via "live streaming" aktivt ha 
deltagit i en våldtäkt som utförts i Filippinerna, medan barnet, som utnyttjats inte får rättshjälp och ersättning. Den snabba utvecklingen av internet har medfört att människohandlarna utnyttjar de sociala medierna som Facebook till att marknadsföra, rekrytera, sälja och utnyttja offer, vilket betyder att människohandeln har flyttats från gatan till den digitala världen. Speciellt utnyttjande av barn online på nätet har ökat kraftigt. Både människohandlarna och offren lämnar spår efter sig som kan identifieras, men detta leder inte till ingripande från polisens sida. Av alla identifierade offer $i$ Holland år 2014, var 84 \% av offren kvinnor, och minderåriga barn utgjorde en femtedel av offren. Idag säljs även nyfödda barn illegalt inom Europa, t.ex. barn från Bulgarien säljs till Cypern och från Rumänien till England.

Bild 3: Rudolf Christoffersen

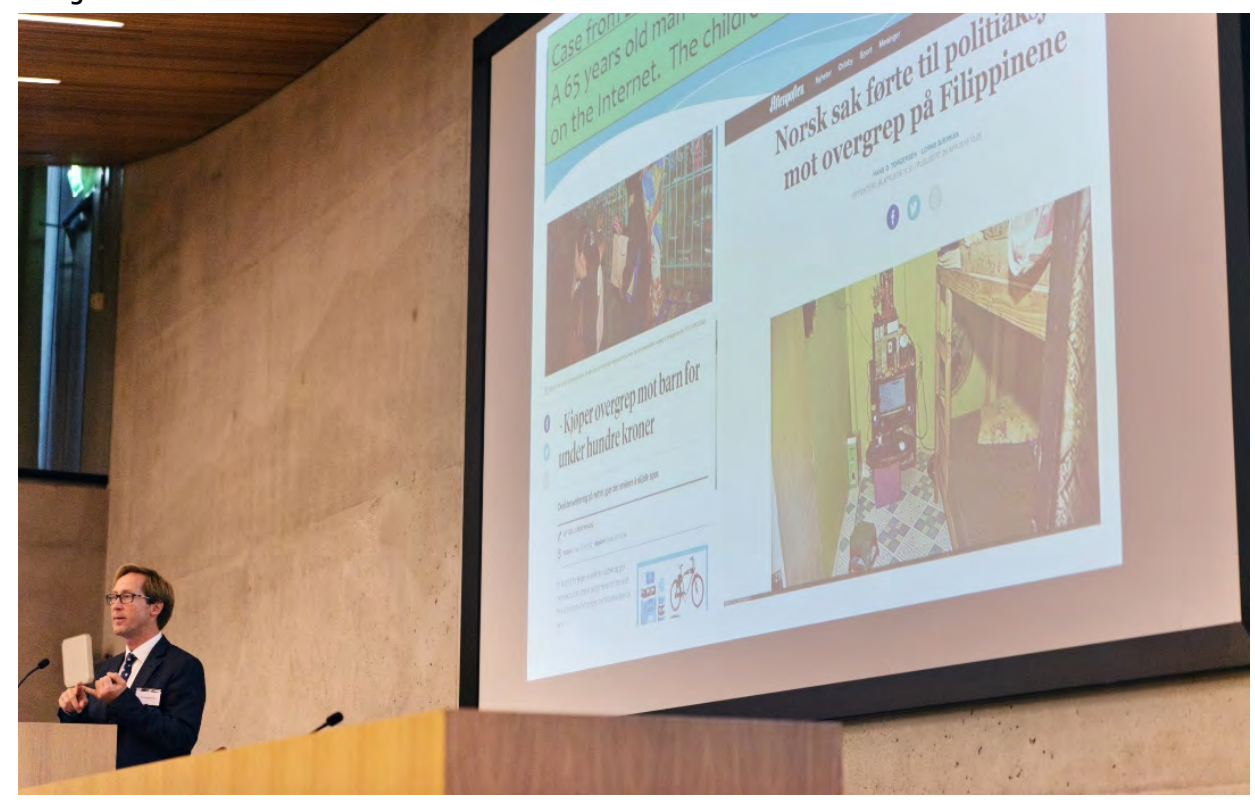

Bidragsbedrägeri, arbetsmarknadskriminalitet och falska ID-handlingar hänger ofta ihop och utgör en stor utmaning för både polis och åklagare. Människohandlarna tar lån, köper varor med stulna kreditkort, och lyfter olika sociala bidrag med falska dokument som betalas in på människohandlarnas bankkonton och ibland lyfter de t.o.m. sociala bidrag samtidigt i flera olika länder. Arbetsmarknadskriminaliteten idag beror på att en låg lön i de nordiska länderna är bättre än ingen inkomst i det egna landet och detta är oftast en blandning av laglig och olaglig verksamhet. Christoffersen berättade om ett rengöringsföretag i Bergen i Norge, som rekryterat personer, som fått avslag på sina asylansökningar, för att arbeta i företaget. Verksamheten hade pågått i över 10 år innan det uppdagades.

Eurojust rapporten Prosecuting THB for the purpose of labour exploitation från år 2015 beskriver sju indikatorer för syftet med utnyttjandet av arbetskraft på arbetsmarknaden såsom brist på språkkunskaper, beslagtagna ID dokument, illegal invandring och skulder. En av orsakerna till få fällande domar är svårigheterna med att bevisa syftet med utnyttjandet. Läs rapporten: 
- http://www.eurojust.europa.eu/press/PressReleases/Pages/2015/2015-12-14.aspx

- https://ec.europa.eu/anti-trafficking/sites/antitrafficking/files/report _on_prosecuting_thb_for_the_purpose_of_labour_exploitation_en_1.pdf

Barn utnyttjas och tvingas att utföra kriminella handlingar, att smuggla och sälja narkotika, att vara ficktjuvar och dessa barn identifieras sällan som offer för människohandel. Barn kan även först vara offer för människosmuggling och senare bli offer för människohandel. I Paris i Frankrike har man ett stort fall med barn från Bosnien, som tvingades att stjäla i offentliga transportmedel, och de kriminella förtjänade över 2 miljoner euro.

Män, som blir offer för människohandel, upplever sig sällan som ett offer, anser sig inte ha några problem och de vill vara män och inte vara sårbara eller ett offer. När de blir upptäckta av polisen kan de ställa frågan: vad har polisen för problem i det här landet, och de säger att polisen ska hålla sig borta från deras vänner.

Christoffersen sade, att unga kvinnor från Lettland, Rumänien, Polen, Tjeckien, Ungern och Slovakien rekryteras för tvångsäktenskap, som är relaterat till människohandel. Dessa unga kvinnor erbjuds mot en summa pengar att gifta sig med invandrarmän från icke-EU länder, för att dessa män ska få uppehållstillstånd i EU. Den juridiska utmaningen i utredning av dessa brott är att EU-länderna har så olika lagstiftning för tvångsäktenskap. Holland har rapporterat om en kraftig ökning av antalet barnbrudar från Syrien som en följd av flyktingkrisen. Över 60 barnbrudar anlände till Holland under perioden september 2015 till januari 2016. Det finns en risk att dessa flickor hålls isolerade och utnyttjas som hushållshjälp. Organhandel ses inte i Norden, vilket beror på att den välfärd och sjukvård som finns i Norden gör att människor inte har så stort behov av att köpa organ. Organhandel sker innan flyktingarna kommer till Europa, när offer säljer organ för att finansiera sin flyktingresa till Europa, t.ex. Libyen har inga regler för organhandel.

Christoffersen sammanfattade de trender som man har sett under år 2016:

- ökat utnyttjande av minderåriga barn

- ökad arbetsmarknadskriminalitet

- cyberkriminalitet, som online sexuellt utnyttjande av minderåriga flickor och pojkar.

Christoffersen sade att eftersom människohandlarna hela tiden utvecklar nya metoder för att utnyttja kvinnor och män och flickor och pojkar på olika sätt, så krävs en ökad kompetens och specialisering inom polis och åklagarkår. Nationella kompetensgrupper inom rättsväsendet skulle garantera att utredning av människohandelsbrott blir prioriterade och att det finns kunskapen om människohandel hos polis och åklagare. Christoffersen avslutade med att säga: "Om du inte vet vad du letar efter, så ser du det inte heller". 


\subsection{Barn, flyktingar och människohandel}

Universitetslektor, docent i rättsvetenskap Märta Johansson, Örebro universitet, Sverige, inledde med att beskriva den kartläggning om människohandel med barn som publicerades i Sverige sommaren 2015 och sade att rapporten skulle ha sett annorlunda ut om den hade presenterats efter den stora flyktingvågen hösten 2015. Johansson beskrev den svenska lagstiftningen om människohandel ( $\operatorname{BrB} 4: 1 a)$, som är byggd på Palermo protokollet. Om ett människohandelsbrott gäller flickor och pojkar behöver åklagarna inte bevisa att ett medel, som olaga tvång eller vilseledande, har använts, det är tillräckligt med en handelsåtgärd och ett syfte att exploatera, för att utgöra människohandel med barn. Johansson presenterade de fakta, som samlats in, om de barn som misstänkts vara offer för människohandel. Alla kommuner i Sverige kontaktades för att erhålla information om barn som offer för människohandel.

Bild 4: Märta Johansson

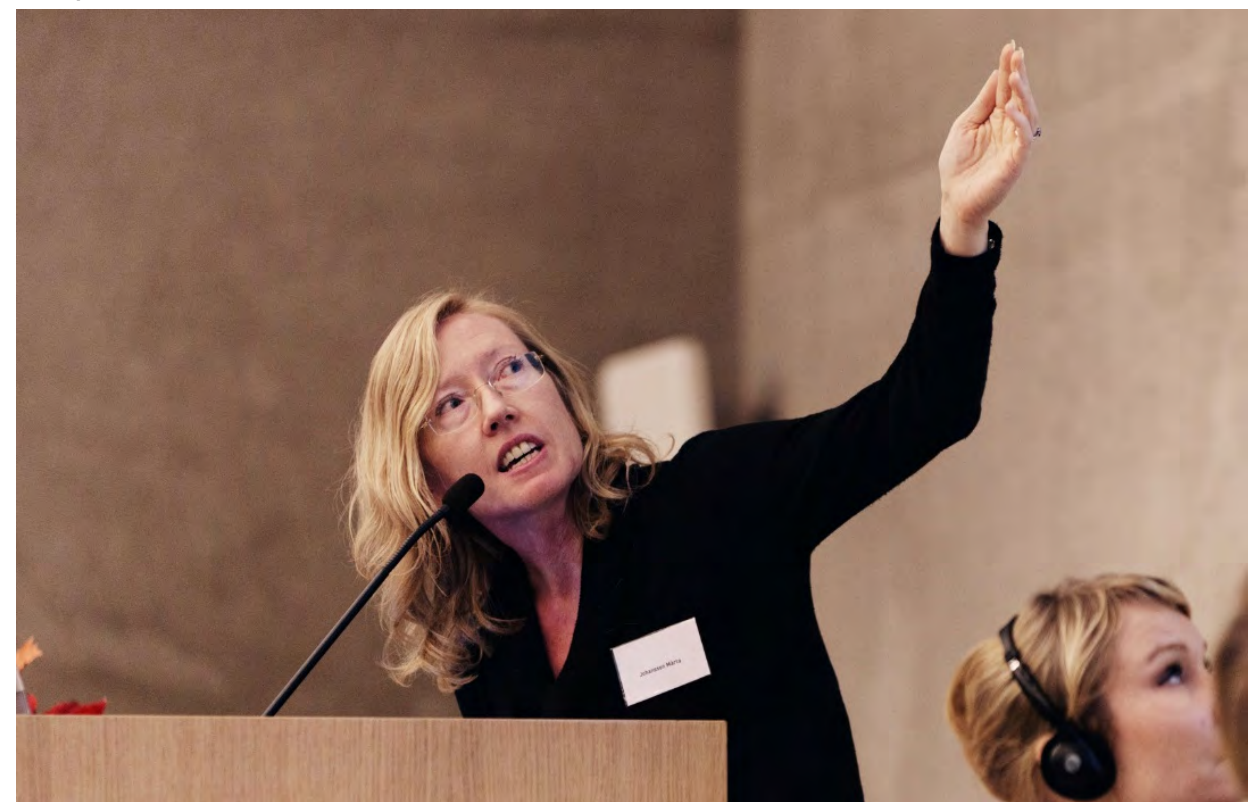

Myndigheter och organisationer hade totalt identifierat 210 barn, av vilka $54 \%$ var flickor/unga kvinnor och $46 \%$ var pojkar/unga män och de flesta, $72 \%$ av flickorna, var mellan 15-17 år. De flesta barn kom från Afrika (44\%), en stor del av dem från Algeriet och Marocko, och andra grupper var bl.a. från Asien (16,5\%) och från Sverige $(8,5 \%)$. De flesta var ensamkommande barn (64\%), och av dessa var $54 \%$ asylansökare. Särskilt utsatta var de ensamkommande asylsökande barnen och de barn, som hade skulder för resan. Andra grupper var: ensamkommande barn, som inte söker asyl, barn som är EUmedborgare, som t.ex. anländer med en vuxen, som inte är barnets vårdnadshavare, eller barn, vars vårdnadshavare var offer för människohandel. Människohandel för sexuellt utnyttjande utgjorde den största gruppen av misstänkta exploateringsformer, totalt $41 \%$ (flickor $44 \%$ och pojkar $27 \%$ ) och resten var bl.a. tvångsarbete, avlägsnande av organ, krigstjänst, tiggeri. En grupp av barn, som var misstänkta som offer för människohandel, 
var de barn som försvann och kom tillbaka, och som inte mådde bra när de återvände och hade med sig t.ex. mycket dyra kläder.

Johansson beskrev de utmaningar som förekommer i samband med misstankar om barn som offer för människohandel. Av de totalt 174 fallen om misstankar i Sverige under 2012-2015 polisanmäldes $45 \%$ och i $47 \%$ av fallen inleddes polisundersökningar, men undersökningarna ledde inte till ett endaste åtal. Barnets berättelse låg bakom 48 $\%$ av polisanmälningarna. Johansson ställde frågan: vad är "tillräckliga misstankar"? Enligt kartläggningen uppstod misstankar utgående från barnets egen berättelse för representanter för socialtjänsten och migrationsverket, omständigheter kring barnets resa till Sverige, barnets försvinnande, kontakter och vuxna kring barnet och/eller tillgång till vissa saker, som dyra kläder, datorer, m.m. Johansson påpekade att utsatta barn är mycket försiktiga med att berätta sina historier och ger få detaljer om misstankar om utnyttjande och människohandel.

Johansson avslutade sin presentation med att beskriva vilka åtgärder i framtiden som skulle behövas för att stöda arbetet med att motverka människohandel med barn. Johansson sade att det i Sverige borde finnas en central funktion för inrapportering av misstänkt människohandel med barn. Myndigheter borde automatiskt rapportera sina misstankar till polisen och polis och åklagare borde få kunskap och resurser till att utreda polisanmälningar som inte föregåtts av spaningsinsatser. Förundersökningsledare borde vara bättre på att använda betänketid (reflektionsperiod) och ge barnen en säker placering. Under åren 2012-2015 gavs enbart $22 \%$ av barnen en säker placering under polisutredningarna.

Bild 5: Lisa Green

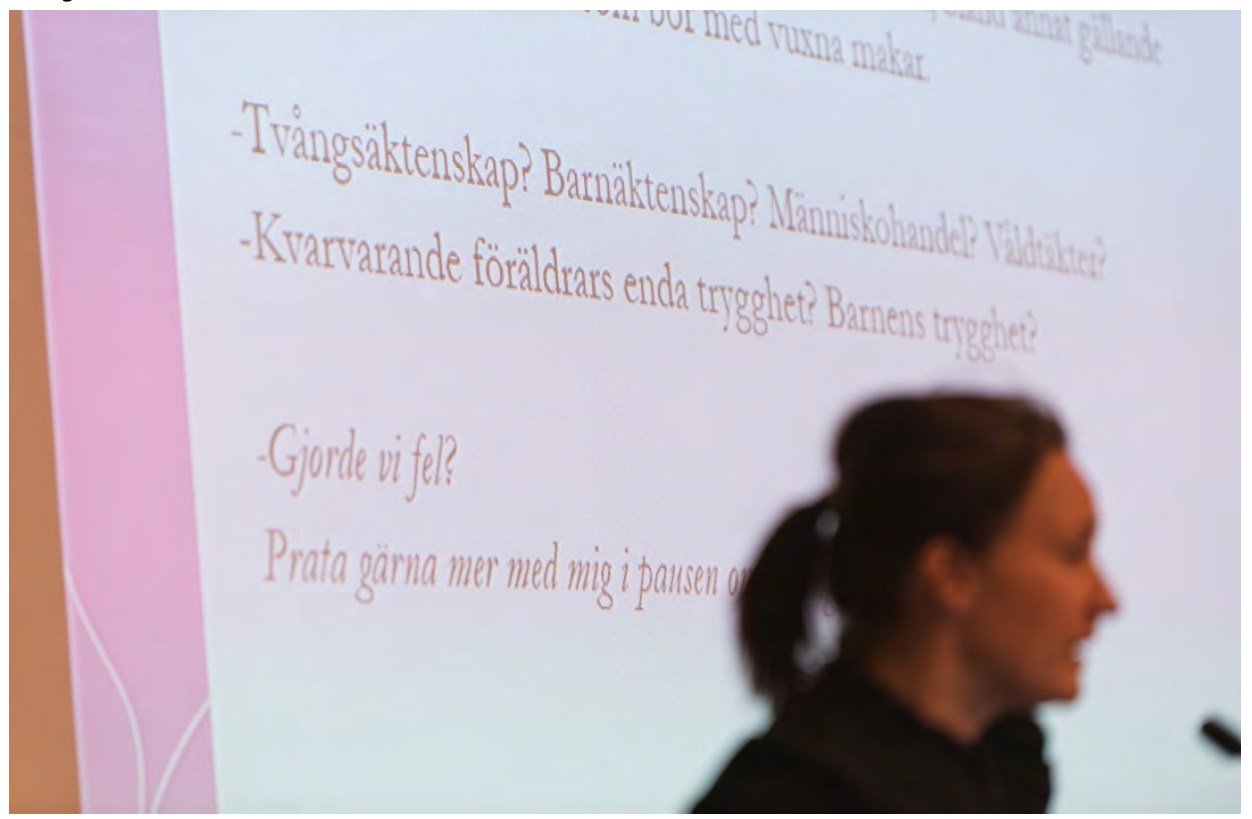

Länskoordinator mot människohandel Lisa Green, Malmö, Sverige gav en presentation om det konkreta arbetet med flyktingbarn som utfördes under hösten 2015 när stora grupper av flyktingar anlände till Malmö. Alla socialarbetare i staden sattes in i arbetet 
med att registrera och hitta boende åt flyktingarna och 100 extra personer anställdes för att arbeta med de flyktingar som ankom till Malmö. Alla personer arbetade under stor press, och blev tvungna att efter en kort intervju med flyktingar och barn ta beslut om var barnen skulle bo. Nya boende öppnades varje dag och idrottshallar fylldes med flyktingar och IKEAs alla lager på madrasser och sängkläder tömdes. Under en natt anlände 300 barn och då låg ansvaret för placering av barnen på de 3-4 socialarbetare som arbetar under nattpasset. Det kunde också komma ett besked om att efter 10 minuter anländer 150 barn. Green beskrev, hur det var att på kort tid ta ställning till, vilket förhållande ett barn har till den fullvuxna personen, som barnet reser med, och om det fanns en risk för att barnen kunde vara offer för människohandel. Barn separerades från anhöriga. Socialarbetarna skulle ta ställning till om flickor/unga kvinnor skulle sättas i anläggningsboende eller i eget boende. Det var viktigt att berätta för flyktingarna vilka rättigheter lagen i Sverige ger flyktingar och ge dem kunskap om barnens rättigheter och berätta för dem att de inte är tvungna till att bo tillsammans med en storabror som slår dem.

Lisa Green sade att som länskoordinator mot människohandel har hon en stor kunskap om den risk det finns att de flickor och pojkar som anlände kunde vara offer för människohandel. Det är ofta svårt att bevisa att fallet handlar om människohandel. Socialarbetarna gjorde en skyddsbedömning utgående från en lista med frågor som ska besvaras och åtgärder som ska genomföras, innan barnet och den vuxna kan sändas vidare till ett boende. Den viktigaste frågan med arbetet i Malmö var, att skapa trygghet för de flyktingbarn som anlände till Sverige. 


\section{Tema: Utmaningar $\mathrm{i}$ rättsprocesser}

- Moderator: Helle Just Krag, advokaturchef, Københavns Politi, Danmark

Advokaturchef Helle Just Krag gav en kort introduktion till Operation Hvepsebo, som har kallats det hittills största fallet om människohandel och ekonomisk kriminalitet i Danmark. Fattiga rumäner lockades till Danmark med falska löften om arbete, och deras identiteter utnyttjades i svindel, medan de tvingades att bo under eländiga förhållanden. Den danska polisen har i en Joint Investigation formellt samarbetat med Rumänien för att utreda fallet.

Bild 6: Helle Just Krag

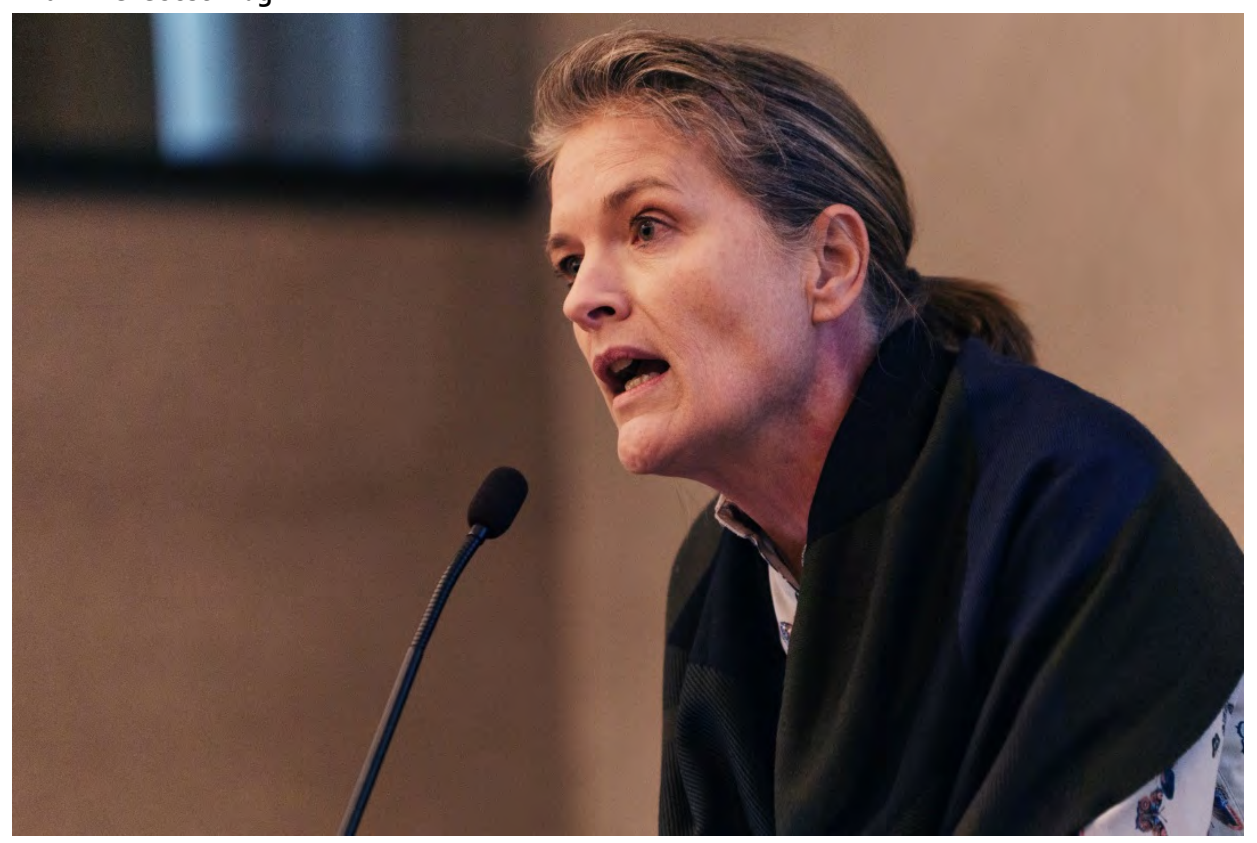

Operation Hvepsebo är speciell eftersom de misstänkta offren rent juridiskt har utfört ett bedrägeri, och de kriminella handlingarna har gjorts i deras namn. Det är första gången att en anklagarmyndighet i Danmark har försökt att få de anklagade dömda för att missbruka oskyldiga människors identiteter för människohandel och bedrägeri.

I fallet Operation Hvepsebo har åklagarna väckt åtal om människohandel, grovt bedrägeri och användning av telefon i fängelse och det har delats upp i tre rättegångar. Hittills har totalt 19 personer dömts för människohandel med 40 personer och för ett totalt belopp på 31 miljoner danska kronor (ca 4,13 miljoner euro). 


\subsection{Identifiering av offer för människohandel}

Anders Morville, politiassistent, Task Force Indbrud, Nordsjællands Politi, Danmark, startade sin presentation med att berätta hur den danska polisen år 2014 upptäckte fallet i förbindelse med en utredning om inbrott och stölder. Polisen misstänkte en arab för att vara ledare för och inkvartera en grupp kriminella och att sälja stöldgods och startade telefonavlyssning av den arabiska mannen. Polisen får information från andra polisregioner i Danmark om rumäner som utför liknande bedrägerier. Den arabiske lägenhetsägaren tas in för förhör, och han berättar att lägenheten är uthyrd till en person från Rumänien. Polisen börjar i slutet av juni 2014 avlyssna rumänaren, som antas ligga bakom stölderna. I processen med avlyssningarna blir det klart att det inte är fråga om inbrott och stölder men om människohandel, där offer utnyttjas för ekonomisk kriminalitet. Fallet visar sig att vara mycket större än vad polisen antagit från början.

Bild 7: Anders Morville

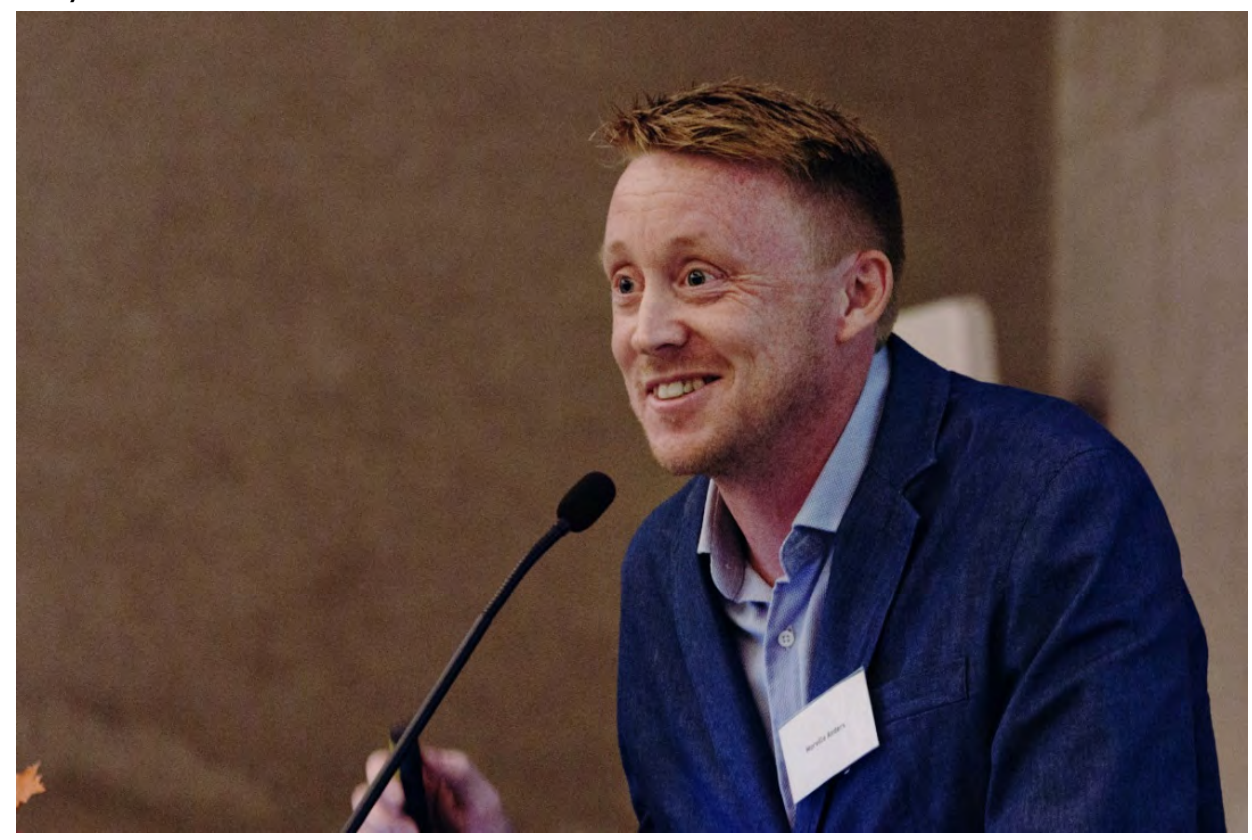

Polisen gjorde en polisrazzia den 25 februari 2015, och rannsakade 62 adresser och anhöll 95 personer. De anhållna indelas i flera celler och polisen följer tre celler för att kartlägga tillvägagångssättet, modus operandi, för rekrytering, transport, logi, hur personer registreras hos medborgerservice, SKAT mm i Danmark. De förmodade offren berättade att de varken hade blivit hotade eller på annat sätt tvingade att resa till Danmark. Bedrägeriet fungerade typiskt så, att en landsman till rumänerna uppsökte och lockade dem till Danmark genom att lova ett arbete med lön inkl. transport, kost och logi. Människohandlarna rekryterade resurssvaga personer, som skulle vara över 30 år, analfabeter och icke kunde tala eller förstå engelska. Vid ankomsten blev de inkvarterade på olika adresser i Danmark. Efter att personerna erhållit ett danskt CPR 
nr. (person nummer), sjukförsäkringsbevis, ett NemKonto (ett bankkonto godkänt av skattemyndigheten i Danmark) och nyckeltalslista till elektronisk användning av bankkontot, blev rumänerna placerade i ett hus för att vänta på ett jobb. Rumänerna bodde aldrig på de adresser, som de hade angett vid sin registrering på medborgerservicen. Människohandlarna hade stor kunskap om det danska social- och skattesystem och de samarbetade med en revisor och en advokat från Danmark.

Efter detta använde människohandlarna dessa dokument till att ta snabblån, hyra bilar och köpa mobiltelefoner och andra varor via internet. De hade dessutom använt offrens identiteter till omfattande skattebedrägerier. Det kriminella människohandelsnätverket grundade företag, som enbart har existerat som pappersföretag, och i vilka de hade placerat offren som direktörer och anställda. Människohandlarna har utbetalat fiktiva löner med hög skatteprocent för att utföra skattebedrägeri och de har fått utbetalt för hög inbetalad förskottsskatt på offrens bankkonton.

Jette Malberg, senioråklagare, Task Force Indbrud, Nordsjællands Politi, Danmark arbetar idag som senioråklagare vid Rigsadvokaten i Köpenhamn och var ledande åklagare för fallet Operation Hvepsebo och berättade att hon under de första månaderna arbetade som enda åklagaren, och det sattes totalt 30 brottsutredare att arbeta med utredningen och till sist arbetade totalt fyra åklagare med utredningen och åtalet. Alla personer som polisen hade funnit på de 62 adresserna förhördes och 22 personer arresterades och skulle åtalas i rätten för människohandel och grovt bedrägeri, men rätten valde dock att endast arrestera personerna för grovt bedrägeri.

Bild 8: Jette Malberg

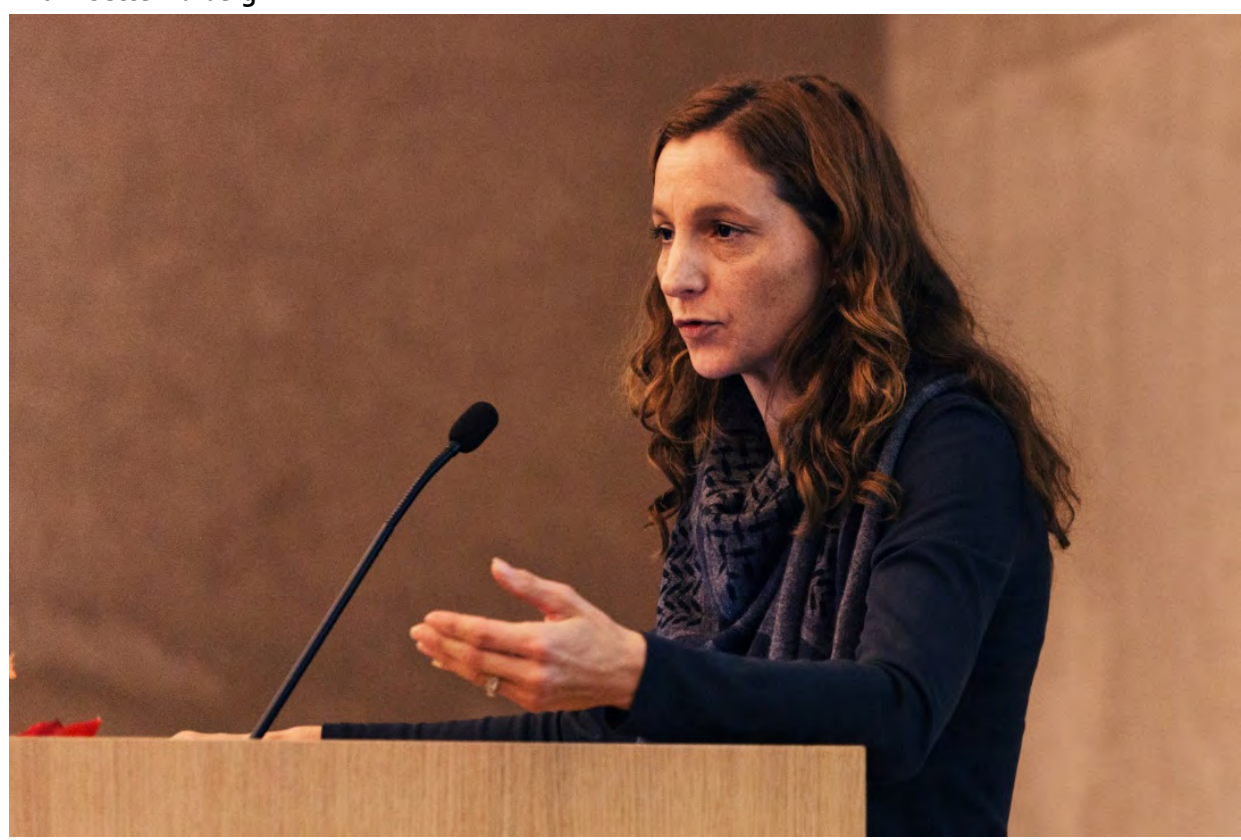

Jette Malberg berättade att det med statsåklagaren (riksåklagaren) blev övervägt noggrant om fallet skulle föras till rätten som bedrägeri eller som människohandel och 
hur de kriminella skulle åtalas. Det olaga tvång, som krävs i människohandelsfall, var inte heller de typiska otillbörliga medlen, eftersom offren inte hade varit utsatta för tvång, hot eller blivit berövande sin frihet. Danmark har inte tidigare haft fall, där offren har varit utsatta för bedrägeri. En annan övervägning var jurisdiktionen, dvs. i vilken rätt fallet skulle tas upp till behandling och vilken den egentliga brottsplatsen var. I detta fall var det svårt att avgöra, eftersom det både kunde vara den plats där personerna rekryterades, där de placerades att bo i Danmark eller där brotten hade begåtts. I detta fall var det internetet, där offrens identitet hade utnyttjats. Beslutet blev åtal om människohandel och resultatet var att fallet delades upp i tre celler och placerades vid tre olika domstolar. Totalt handlade det om 1.000 bedrägerifall. Hela utredningen var mycket omfattande och den krävde mycket resurser:

- Cell 1 var det största fallet och bestod av huvudmannen och 13 medhjälpare.

- Cell 2 var sammansatt av två mindre organiserade celler och fem personer blev åtalade.

- Cell 3 bestod av en syskonfamilj och tre personer blev åtalade.

Det mest utmanande i fallet var att bevismaterialet var oerhört stort. Totalt fanns det 100.000 posteringar med avlyssningsmaterial (SMS, telefonsamtal, missade samtal), av vilka över 10.000 samtal blev använda i utredningen. Malberg påpekade att det största problemet var att välja vad som skulle läggas fram i rätten. Det fick inte vara för mycket eller för lite.

Det var också utmaningar med vittnen. Mellan 300-400 personer hade gått igenom "bedrägerihärvan", fått ID-dokument och utnyttjats av de kriminella. I fallet utnyttjades 200 personers identitet i olika bedrägerier. Man valde att lyfta åtal om människohandel för utnyttjande av totalt 70 personer. Rätten ansåg att 40 personer, som avgett vittnesmål, hade utsatts för människohandel och man förväntade att kunna avhöra dem under rättegången. I alla tre fallen väcktes åtal för människohandel, samtidigt som det också blev väckt åtal för bedrägeri, grovt skattefusk och användning av mobiltelefoner $\mathrm{i}$ fängelse.

De personer, som åtalades i fallet om cell 3 , blev dömda för människohandel av tre personer och för grovt bedrägeri för totalt 900.000 danska kronor (ca 120.000 euro). Rätten avslog åtal för utnyttjandet av 15 personer för människohandel. Rätten lade vikt vid att alla offer kom från den samma lilla landsby, och motiveringen var att det inte kunde vara fråga om vilseledande, eftersom de personer, som återvänt från Danmark, hade berättade att de inte hade fått arbete såsom utlovats. Domen var mellan 2-3 års fängelse och alla dömdes till utvisning från Danmark. Domen överklagades, och fallet har behandlats i Landsretten (Hovrätten) och Højesteret (Högsta domstolen) i Danmark. Domarna skärptes till 3 år och $3^{1 / 2}$ års fängelse.

I fallet med cell 1 åtalades 13 personer, och 12 rumäner blev dömda för människohandel med 19 personer. Rätten ansåg, att det var fråga om vilseledande av 16 personer och att alla personer hade utsatts för ett otillbörligt medel. Människohandlarna dömdes för grovt bedrägeri och skattefusk för 10,4 miljoner 
danska kronor (ca 1,38 miljoner euro) till mellan 7 år och 11 månader och 3 års fängelse. Danskarna blev frikända för människohandelsbrott. Tre personer överklagade domen till Landsretten (Hovrätten) i Danmark, och Landsrettens dom för de två personer som hade dömts för människohandel, förblev det samma som i Byretten (Tingsrätten). Den person, som blev frikänd i Byretten, blev också frikänd för människohandel i Landsretten och fick sitt straff nedsatt till 5 år och 6 månader.

I fallet med cell 2 blev fem personer åtalade (tre rumänska och två syriska medborgare). Fyra blev dömda för människohandel med 18 personer. Alla blev dömda för bedrägeri för 4,8 miljoner danska kronor (ca 640.000 euro). En person dömdes för grovt skattefusk för 16,4 miljoner danska kronor (ca 2,18 miljoner euro). Straffen var mellan 3-7 års fängelse och alla blev utvisade från Danmark. Fallet har överklagats till Landsretten (Hovrätten) i Danmark.

Total har 19 personer dömts för människohandel med 40 personer och för bedrägeri för total 31 miljoner danska kronor (ca 4,13 miljoner euro). De flesta offren är män (116), medan 15 kvinnor blev utnyttjade. I alla tre fallen fanns även kvinnor som utförde kriminella handlingar. Rättegångsmaterialet bestod av totalt 6.500 sidor och domsluten var på totalt 178 sidor.

\subsection{Människohandel och utmaningar i polisutredningar}

Olafur Kjartansson, polischef, Suðurnes polisdistrikt, Island, gav en översikt över människohandel i Island och hur polisen har arbetat med att utveckla insatsen mot människohandel både inom polisen och rättsväsendet. Polisen har i samarbete med de sociala myndigheterna och medborgarorganisationer också utvecklat ett hjälpsystem för offren för människohandel. Kjartansson presenterade hur polisen utbildas i att identifiera både människohandlare och offer för människohandel. Idag är det helt klart att människohandel finns i Island, även kvinnor från afrikanska länder sänds till Island för att bli sexuellt utnyttjade.

År 2010 fällde Islands Högsta domstol sina två första domar angående människohandel och sexuellt utnyttjande. I det ena fallet var det en afrikansk kvinna, som lockat en kvinna till Island och sålde henne som prostituerad. Hon smugglade också narkotika till Island och hon dömdes till 3 år och 6 månaders fängelse. Det andra fallet handlade om en litauisk flicka, som blev sänd till Island. Fem baltiske medborgare dömdes för människohandel, en dömdes till 5 års fängelse och fyra blev dömda till 4 års fängelse.

I februari år 2016 blev ett nytt fall om människohandel behandlat i rätten i Island. En utländsk person åtalades för att hämta två kvinnor från Sri Lanka till Island, och för att utnyttja dem som billig arbetskraft under dåliga arbetsvillkor. Kvinnorna fick knappast någon lön för sitt arbete. För polisen har undersökningen av fallet varit komplicerad eftersom det har varit svårt att avgöra om det är fråga om tvångsarbete eller dåliga arbetsvillkor och underbetalning eller utnyttjande av arbetskraft.

Dessa fall visar tydligt att människohandel existerar i Island, men för polisen är det svårt att upptäcka fallen. En väsentlig orsak är att offren inte har kunskap om sina 
rättigheter eller att de av olika personliga orsaker inte önskar att komma ut ur den situation de befinner sig i eller att samarbeta med polisen.

Bild 9: Olafur Kjartansson

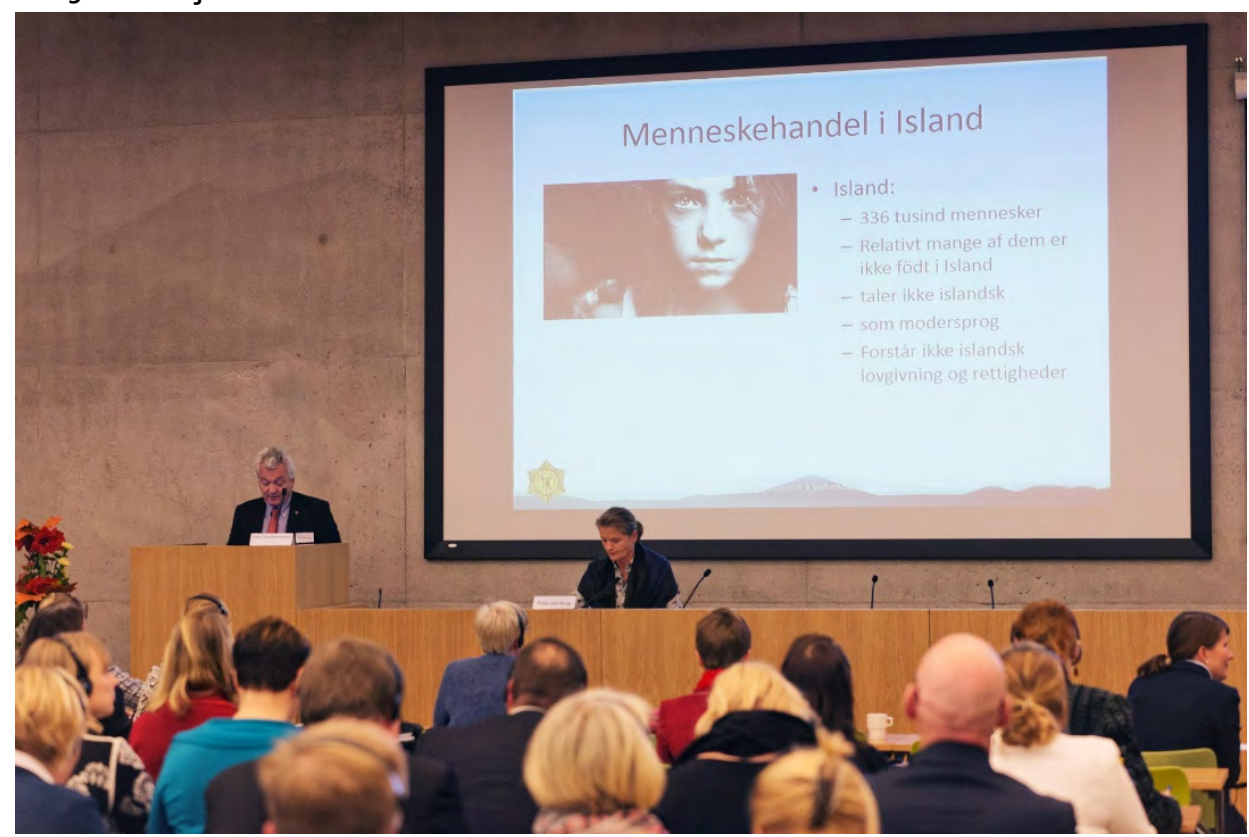

Polisen har ofta misstankar om att arbetare från andra länder missbrukas på en arbetsplats, att de får lägre lön än islänningarna, att de tvingas att bo under usla förhållanden och på ett sätt som islänningar under inga omständigheter skulle acceptera. Kjartansson sade att redan år 2003 misstänkte polisen att det i ett fall, som handlade om en isländsk arbetsgivare, som hade rekryterat baltiska arbetare till Island, var frågan om människohandel. De baltiska arbetarna hade inte arbetstillstånd, vilket ännu år 2003 krävdes av baltiska medborgare för att arbeta i Island, så balterna åtalades för att illegalt arbeta i Island. Polisen kunde inte bevisa att arbetsgivaren hade brutit mot lagen. Balterna fick en villkorlig dom för att ha arbeta olagligt i Island. Både arbetsgivaren och de baltiska arbetstagarna påstod, att balterna var i Island för en provanställning, för att komma underfund om de önskade att arbeta i Island. Fallet visar tydligt hur svårt det är att bevisa kriminella handlingar i samband med människohandel, när de personer, som utnyttjas av en eller annan orsak, väljer att inte samarbeta med polisen. Det var helt klart att personerna hade utnyttjats, att de inte kände till sina rättigheter eller den isländska arbetslagstiftningen. Detta beror ofta på att personer, som utnyttjas, kommer från länder med dåliga arbetsvillkor och stor arbetslöshet och anser att allt ser bättre ut i det nya landet. Kjartansson sade att fallet visar också hur svårt det är att få ett fall om tvångsarbete behandlat $\mathrm{i}$ en isländsk domstol.

Fall med barn har även gett upphov till misstankar om människohandel. Polisen undersökte ett fall med en man från Balkan, som kom till Island med en ung pojke, som mannen påstod var hans son. I polisutredningen visade det sig att pojken hade anmälts 
försvunnen i sitt hemland av sina föräldrar. På grund av bristande på bevisföring kunde mannen inte åtalas.

Kjartanson sade att det är en stor utmaning för den isländska polisen att identifiera offer för människohandel och upptäcka förhållanden som kan misstänkas vara människohandel. Det är viktigt att polisen i Island samarbetar med andra myndigheter och experter, som socialrådgivare, psykologer, läkare, lärare och dessutom med andra länder i samband med utredningar av människohandel. Det kräver mycket polisarbete att undersöka människohandelsfall och polisen måste ha specialkunskaper och experter till sitt förfogande för att klara av att utreda dessa fall, som ofta dessutom är mycket komplicerade. Speciellt sexuellt utnyttjande kan vara besvärliga fall att utreda.

Information till allmänheten är viktig, för att människor ska kunna lära sig att identifiera möjliga fall med människohandel i sin närmiljö och för att belysa problematiken kring människohandel. Speciellt svårt är människohandel med kvinnor och barn. Kjartanson avslutade med: "Trots att det är resurskrävande för polisen och det kan ta lång tid att utreda fall om människohandel är det en plikt för polisen att göra det och utnyttja den moderna tekniken så gott vi kan. Det är vår plikt. Vi får aldrig ge upp." 



\section{Tema: Kvinnor och män som offer för människohandel}

- Moderator: Mikko Sipilä, häradsåklagare, åklagarämbetet i Östra Nyland, Finland.

\subsection{Psykiska konsekvenser av sexuellt utnyttjande och rättsprocessen}

Maija Koskenoja, överinspektör vid Diskrimineringsombudsmannens byrå i Finland, presenterade ett modellagenturfall i Finland, om en ung kvinna, som önskade att göra karriär som internationell modell. Kvinnan blev under den första arbetsintervjun lurad till att låta ta nakenbilder av sig. Modellagenturens direktör använde nakenbilderna som utpressning, och kvinnan tvingades att sälja sexuella tjänster till kunder, som direktören, förmedlade. Koskenoja presenterade hur förövaren får makt över sina offer och vilka de psykiska konsekvenserna av människohandeln och det sexuella utnyttjandet är för offren och deras familjer. Direktören gav en falsk bild av sig som en inflytelserik aktör i modellvärlden, när han de facto ledde ett företag med erotiska programutbud. Modellagenturfallet hade totalt 25 målsägare. Direktören åtalades $\mathrm{i}$ detta fall, som Koksenoja presenterade, i en åtalspunkt för människohandel och i över 20 åtalspunkter för olika sexuella brott. Direktören blev total dömd i Tingsrätten för alla brott, mot de totalt 25 målsägarna, för både människohandel och ett tiotal sexualbrott till totalt 12 år och 6 månader, som Högsta domstolen (HD) ändrade till total 10 år och 6 månader, och för alla målsägandens del blev han inte dömd för människohandel. Mannen dömdes att betala ca 200.000 euro i ersättningar till de involverade målsägandena.

Koskenoja sade att för att en domstol ska tro på att ett offers berättelse är sann, krävs att expertvittnen används under rättegången. Hon poängterade, att expertvittnen ska användas i rättsprocessen, för att bevisföringen och bedömningen av bevisen ska ge offren en rättvis behandling, och för att offren ska kunna erhålla ersättning för de skador som de fått. Offret bodde hemma, gick i skola, tog studentexamen, d.v.s. var en mönsterelev och samtidigt fortsatte det sexuella utnyttjandet och manipulationen av offret. Offret hade kontaktat polisen för att få hjälp om hur hon kunde bryta kontraktet, men polisen hade enbart sagt att hon hade stött på en skojare och fått ett dåligt arbetskontrakt. För att förstå offrets beteende behövs expertvittnen, som terapeuter och experter från den psykiatriska polikliniken och rättspsykiatriska enheten offret har besökt och vårdats av. I rätten bör beskrivas det sexuella utnyttjandets dynamik baserat på den terapeutiska och psykiska behandlingen och de vetenskapliga bevisen om följderna av sexuellt utnyttjande. Frågor som: Vad 
betyder manipulation? Är utnyttjandet förbundet med skam och skuld? Finns det erfarenheter av, att den utnyttjade inte flyr, skriker, lämnar situationen hon hamnat i är viktiga att ta upp under rättegången.

Koskenoja beskrev hur utnyttjandet bedömdes i de olika rättstadierna. Helsingfors tingsrätt (2011) ansåg att på basen av de framförda bevisen hade rekvisiten uppfyllts och att modellagenturens direktör hade gjort sig skyldig till människohandel, och slutsatsen var att offret hade grava traumatiseringssymptom, som enligt experterna var typiska för en person som blivit utnyttjad. Följande rättsinstans Helsingfors hovrätt (2013) ansåg att störningarna i offrets psykiska hälsa var resultat av svarandes förfarande och beror på att svaranden har utövat makt över offret. HD i Finland (2015) hade en annan åsikt, och ansåg att människohandelsbestämmelsens rekvisit om att utöva makt inte uppfyllts i modellagenturfallet. Koskenoja sade att HD inte hade använt sig av muntliga förhör som de två första rättsinstanserna, utan enbart tagit del av det skriftliga materialet, och på detta sätt hade HD:s medlemmar inte själva kommit i kontakt med offret, för att avgöra offrets psykiska tillstånd. Koskenoja sade att det bl. a. behövs ändringar i lagstiftningen, en förståelse för offerbeteendet och traumatiseringen och en struktur för bedömning av det psykiska tillståndet. Koskenoja sade att det skulle behövas expertgrupper inom olika myndigheter som har sakkunskap och erfarenhet om rekryteringar, utnyttjande och bekämpning av människohandel. Hela fallet tog 6 år av offrets liv, och hennes psykiska tillstånd var hela tiden dåligt och hon har varit intagen på psykiatriskt sjukhus. Fallet har även haft konsekvenser för offrets familj, som har resulterat i svårigheter med skolgång och deltagande $i$ arbetslivet. Idag är lagstiftningen ändrad så att den bättre reflekterar en förståelse för gärningsmannens psykologi.

Detta konkreta fall från Finland beskriver hur människohandel även kan ske inom ett land, och att människohandel inte behöver vara en kriminell gränsöverskridande handling, som måste ske från ett land till ett annat. Koskenoja tog även upp hur människohandel för sexuella ändamål har ett tydligt könsperspektiv och att i de flesta fall av sexuellt utnyttjande är det en kvinna eller flicka som är offret och en man som köper de sexuella tjänsterna. Människohandlarna och de som rekryterar kvinnorna kan vara både kvinnor och män.

\subsection{Får offren - både kvinnor och män - den hjälp de behöver?}

Leila Langdalen Sbai, informationsrådgivare från ROSA, Krisesenter i Oslo, Norge och Kristin Berntsen, teamledare på Mottak Oslo Krisesenter, Norge berättade i presentationen om organisationernas arbete med att hjälpa de personer som blivit offer för människohandel och om den hjälp offren, både kvinnor och män, kan få när de kontaktar ROSA och Mottak på Oslo Krisesenter.

Leila Langdalen Sbai startade med att berätta hur ROSA och Oslo Krisesenter samarbetar med att hjälpa och beskydda personer över 18 år, som är offren för människohandel. ROSA har från början haft 2 anställda medarbetare och har nu genom en nyetablerad hotline fått ytterligare en medhjälpare och verksamheten finansieras av 
Justitiedepartementet i Norge. ROSAs mandat är att hjälpa och säkra ett tryggt boende för personer som är offer för människohandel och har utnyttjats i prostitution och har inga egna bostäder. Arbetet föregår både per telefon och i Oslo, genom personliga samtal och hänvisar offren till kriscentren runtom i hela Norge. Polisen är den som sänder de flesta av offren till ROSA. ROSA har stött och hjälpt över 1000 personer och totalt ca 500 personer har deltagit i ROSA projektet.

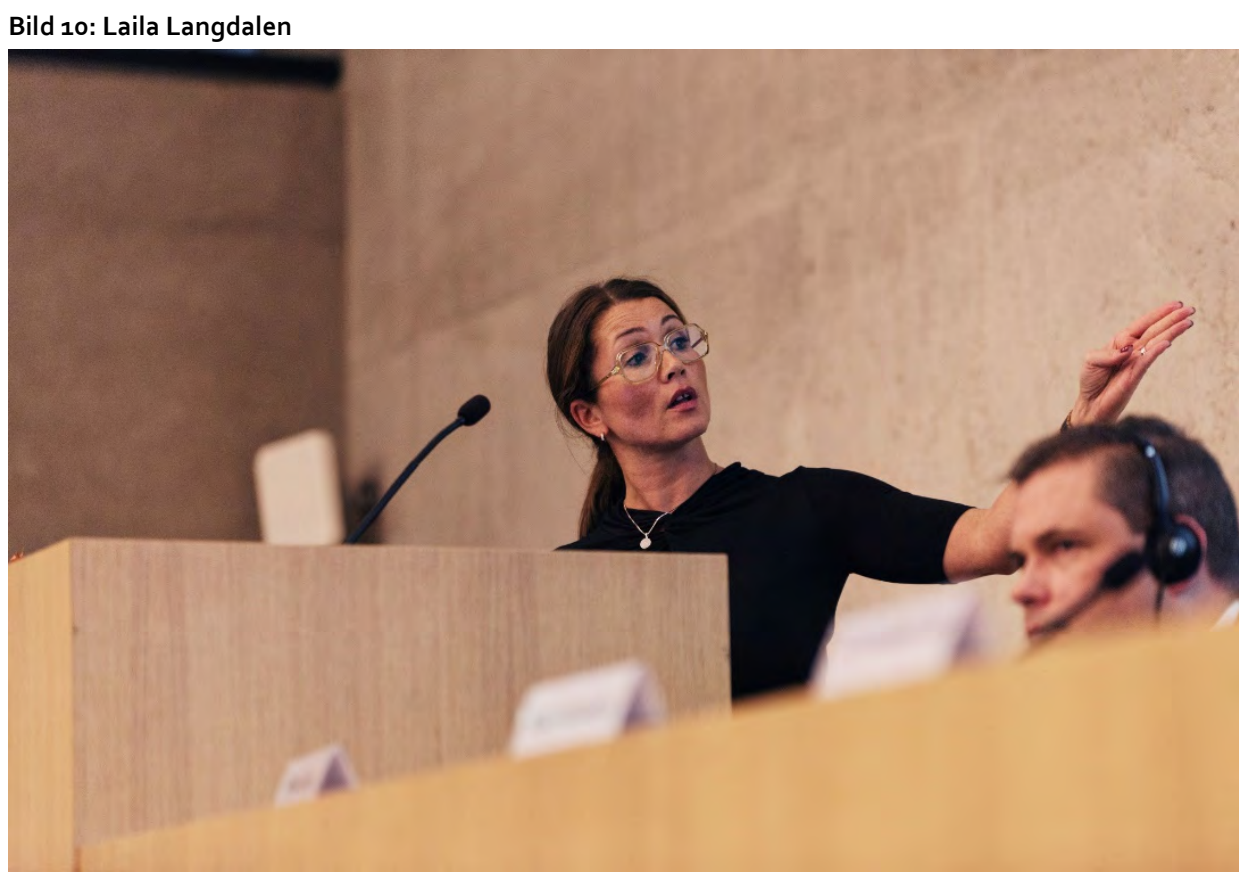

ROSA assisterar även polis, advokater och organisationer som bekämpar människohandel och undervisar även på polishögskolan och journalisthögskolan och arbetar med att sprida information om människohandel. Landalen Sbai sade att de flesta kvinnor kommer från Nigeria, Albanien, Bulgarien, Rumänien och andra östeuropeiska länder, totalt har ROSA varit i kontakt med personer från 6o länder. Den nigerianska gruppen har varit den största under de senaste åren. De flesta offren är mellan 20 och 30 år, men det ser ut som om offren idag är allt yngre personer och många är minderåriga. De flesta offren kommer till Norge från Italien, Spanien, Danmark, och Sverige, de har inga dokument, har stora skulder och kontrolleras genom att de utsätts för fysiskt, psykiskt och sexuellt våld. Gruppen från Nigeria utsätts även för jojo, som är ett mycket effektivt kontrollmedel. Under åren 2014-2016 har även män, som blivit offer för människohandel, kontaktat ROSA. Av 78 första gångs kontakter till ROSA år 2016 var totalt sju män, som blivit utnyttjade på arbetsmarknaden. Landalen Sbai beskrev att män har högre tröskel att ta kontakt med ett kriscenter, men att män även har fått erbjudande om ett tryggt boende. Hon sade att ROSA år 2016 har som något nytt även gett hjälp åt en transperson. Hon beskrev också de olika grupper av barn som under åren 2014-2015 har kommit till Norge. Landalen Sbai avslutade med att säga att ROSA är beroende av att andra sänder offer för människohandel till dem, eftersom de 
inte själva arbetar med uppsökande verksamhet. Det finns idag ett stort behov av information om människohandel.

Kristin Berntsen presenterade Oslo Krisesenters verksamhet och startade med att beskriva den norska Krisesenters lagstiftningen från 2010, som ålägger alla kommuner i Norge att hjälpa kvinnor, män och barn som i nära relationer utsatts för våld. Kriscentret är öppet dygnet runt, upprätthåller en telefonlinje och erbjuder ett skyddat boende. På kriscentret finns en avdelning för skyddat boende, en dagavdelning med rådgivning för kvinnor, som blivit utsatta för olika former av våld, en avdelning för män, som utsatts för våld $i$ en nära relation och ROSA avdelningen, som hjälper offer för människohandel i hela Norge. Oslo Krisesenter är Nord-Europas största kriscenter och på centret bor årligen 350 kvinnor och 300 barn. På avdelningen för män bodde under år 2015 totalt 15 män och 5 pojkar. På ROSA-avdelningen bor årligen mellan 30-40 offer för människohandel. Oslo Krisesenter kontaktas årligen av 175-200 personer. Sedan augusti 2016 kan offer för alla former av människohandel få hjälp, inte enbart offer, som utnyttjats sexuellt. Kriscentret gör tillsammans med ROSA den slutliga identifieringen av offret. En kontaktperson följer offret genom hela rättsprocessen. Berntsen sade också att de psykiska och sociala konsekvenserna för offren är de samma som för de kvinnor som utsätts för våld. Under den tid offren för människohandel bor på ROSA avdelningen får de juridisk hjälp, hälsovård och erbjudande om utbildning för att kunna bygga upp en framtid i Norge.

\section{Bild 11: Kristin Berntsen}

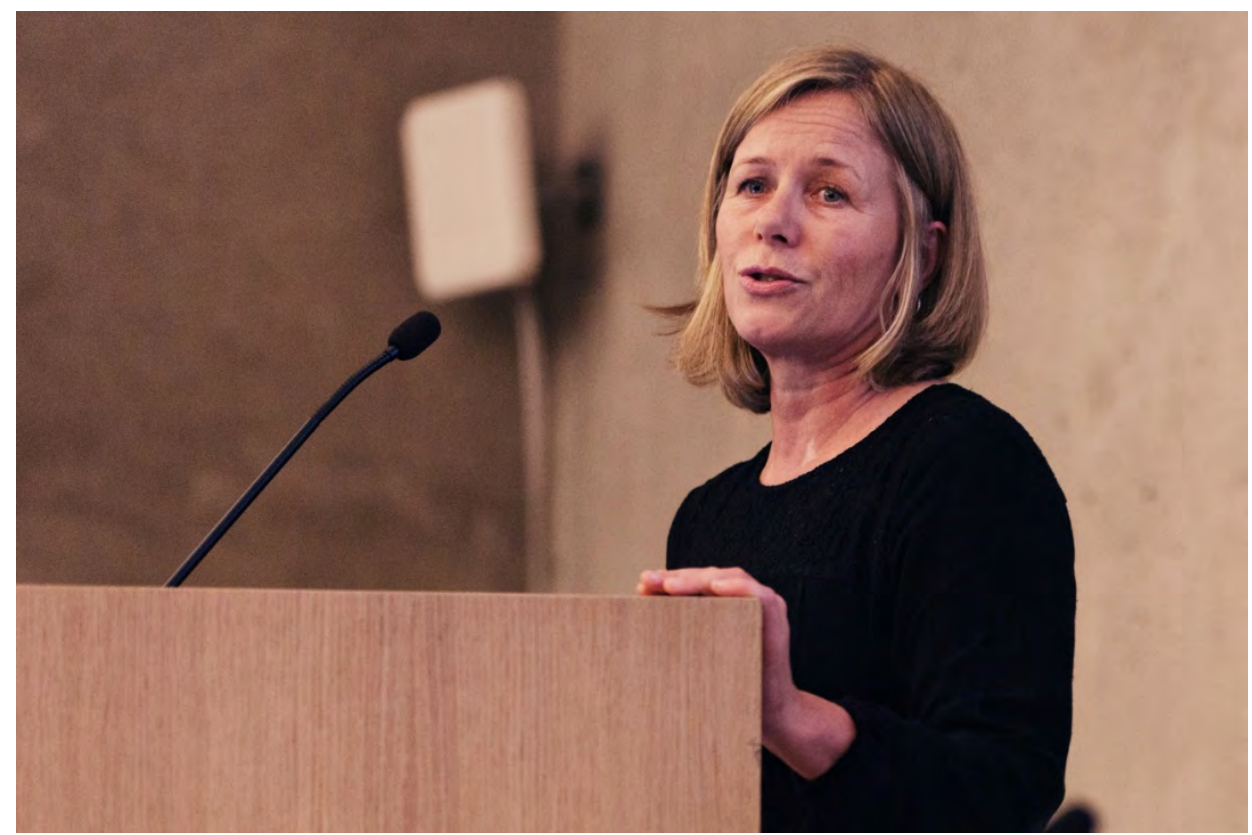




\section{Paneldebatt}

\subsection{Hur kan Norden samarbeta i insatsen mot människohandel?}

- Moderator: Eva Biaudet, riksdagsledamot, Riksdagen, Finland.

Paneldeltagare:

- Anna Katrine Krag Madsen, analytiker, Københavns Vestegns Politi, Danmark

- Malene Muusholm, teamleder, Reden København/Reden International, Danmark

- Laura Sairanen, häradsåklagare, Riksåklagaren, Finland

- Kenneth Eriksson, överkonstapel, Helsingfors polisstation, Finland

- Olafur Helgi Kjartansson, polischef, Suðurnes polisdistrikt, Island

- Thor Martin Elton, politiførstebetjent, Oslo polisdistrikt, Norge

- Helena Ljunggren, kammaråklagare, Internationella åklagarkammaren Malmö, Sverige

Bild 12: Eva Biaudet

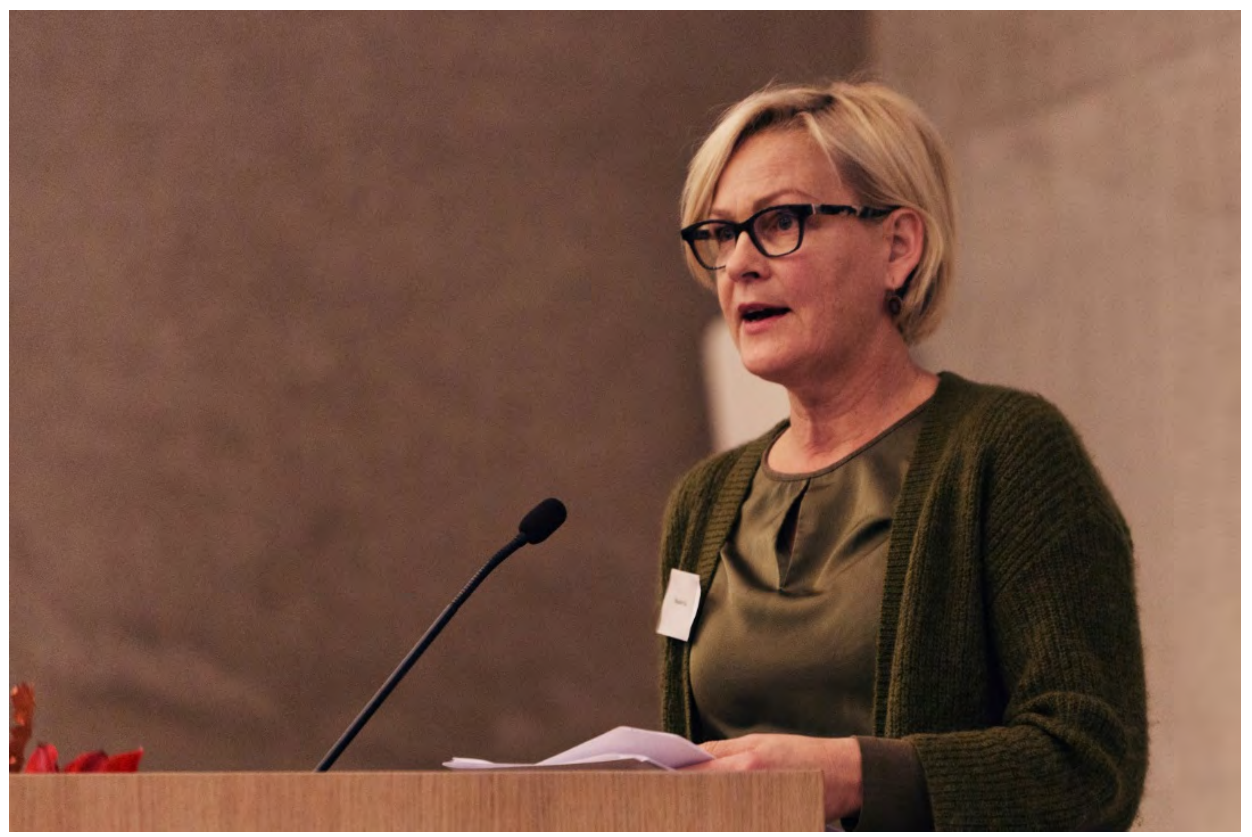


Paneldiskussionen tog utgångspunkt i frågorna:

- Vad kan aktörerna som arbetar mot människohandel lära sig av varandra?

- Hur kan experter bäst utbyta erfarenheter, arbetsmetoder och kunskap?

- Hur kunde samarbetet i gränsöverskridande utredningar se ut i praktiken?

Panelen inleddes med att Anna Katrine Krag Madsen analytiker från Københavns Vestegns Politi i Danmark presenterade den nordiska rapporten Exchange of Information in Cases of Trafficking in Human Beings (TemaNord 2016:542, Nordiska ministerrådet), som har finansierats av Nordiska ministerrådet och blev sammanställd av Rigspolitiets Nationale Efterforskningscenter (NEC) under 2015-2016. Läs rapporten:

- http://norden.divaportal.org/smash/record.jsf?pid=diva2\%3A971195\&dswid=81\#sthash.qfGcPCY6.dpbs

Bild 13: Anna Katrine Krag Madsen

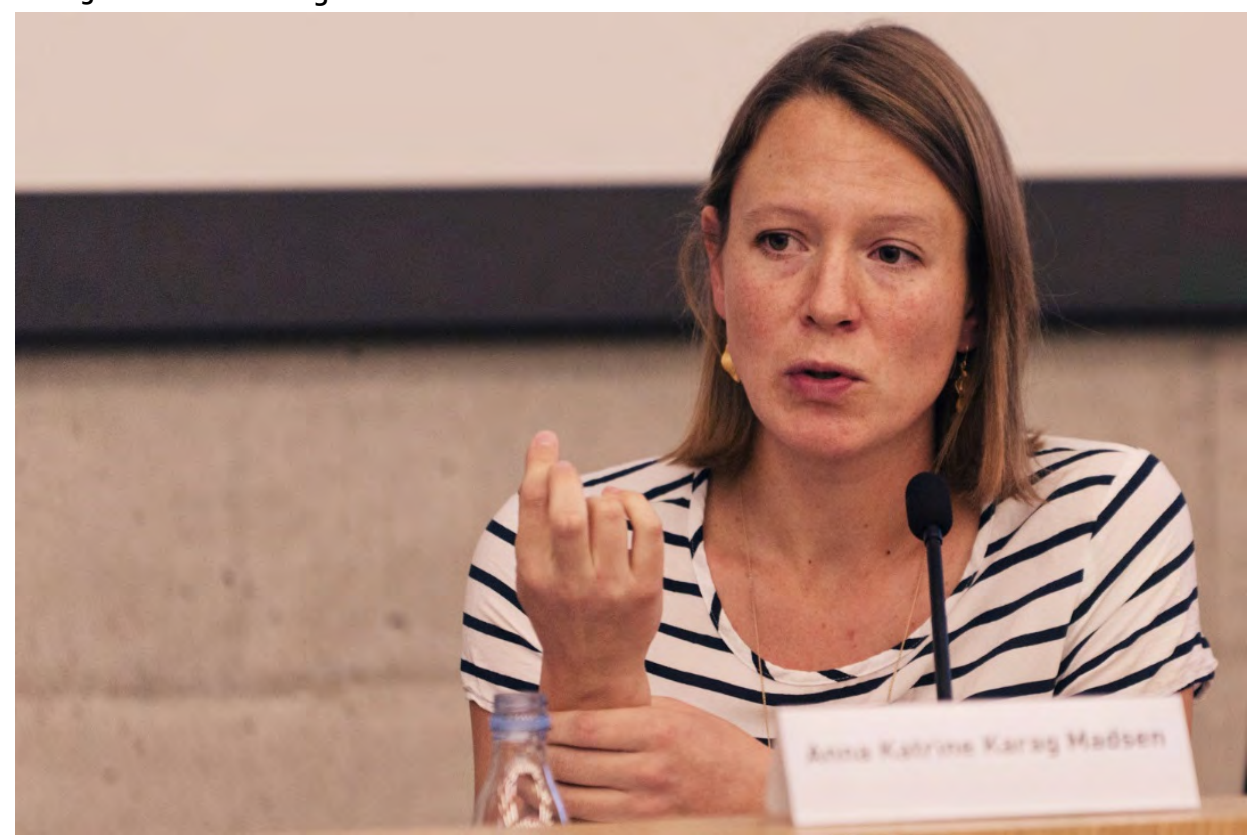

Rapporten presenterar information om hur olika myndigheter och polis i de nordiska länderna utbyter information. De myndigheter, som deltog i undersökningen, och som dagligen hanterar information om människohandel, anser att de sällan behöver kontakta polisen och om de kontaktar polisen frågar de efter en koordinerande enhet för att försäkra sig om att information går fram till rätt enhet inom polisen. Få av de nationella myndigheterna har ansett det vara nödvändigt att kontakta andra nordiska länders myndigheter i frågor om människohandel. Ifall det har funnits behov av att kontakta ett annat nordiskt land har de tagit kontakt med polisen i landet. De 
polismyndigheter, som deltagit i rapporten, har sagt att de har mandat att utbyta information med andra polismyndigheter.

Rapporten föreslår följande utbyte av information mellan de nordiska länderna:

- Utbildning i användning av indikatorer för människohandel.

- Klara kommunikationskanaler mellan myndigheter och polis.

- Organisatorisk prioritering av intern hantering av människohandel hos myndigheter och polis.

En guide med goda praktiker baserad på rapporten har även publicerats av Nordiska ministerrådet. Läs rapporten:

- http://norden.diva-portal.org/smash/record.jsf?pid=diva2\%3A971227\&dswid=2775\#sthash.BFkb7jbp.dpbs

Paneldeltagarna gav en kort inledning om deras syn på människohandelskriminalitet och vilka utmaningar, åklagarmyndighet och medborgarorganisationer har kring identifiering av offer och speciellt med arbetet att övertyga offret om att deras berättelse och vittnesmål är viktiga för rättsprocessen. Det poängterades att det kräver ett gott samarbete mellan polis och åklagare och att ett nordiskt samarbete skulle vara bra eftersom offren för människohandel idag transporteras från ett nordiskt land till ett annat.

Malene Muusholm från Reden International i Danmark berättade att Reden arbetar med uppsökande verksamhet på gatorna i Köpenhamn och för Reden är det viktigt att bygga upp en långvarig relation till kvinnorna de möter. Det är viktigt att det i Reden även finns personer som talar kvinnornas språk och förstår förhållanden i landen de kommer från. Muusholm ansåg att det kunde vara bra att ha liknande samarbete om människohandel med andra organisationer och myndigheter som man har haft under utredningen av Operation Hvepsebo. Det är speciellt viktigt med samarbete om nigerianska kvinnor, som skickas och reser runt mellan de nordiska länderna. Reden har samarbete med norska organisationer, men Reden kontaktar i första hand polisen när de önskar kontakt med eller information från ett annat nordiskt land.

Olafur Helgi Kjartansson sade att polisen borde inleda samarbete med skolorna och hälsovården för att bekämpa människohandel. Det lyckas inte alltid för polisen att få information från andra myndigheter, bl.a. önskar inte läkare ge information till polisen, de hänvisar till sin tystnadsplikt. Nigerianska kvinnor önskar inte heller samarbeta med polisen. Ofta har offren och experterna information, som kunde hjälpa polisen att utreda människohandelsbrott. Kjartansson sade också att i åtminstone 5 fall av narkotikasmuggling i Island verkar det som om utländska kvinnor tvingats att smuggla in narkotika till Island och att det är fråga om människohandel, men den isländska polisen inte har kunnat bevisa att det är fråga om människohandel.

Kenneth Eriksson från Helsingfors polisen i Finland sade att han arbetar med människohandel och prostitution och att det i Finland är ett problem att polisen inte 
har specialiserat sig på människohandel. På lång sikt borde man få en grupp/grupper som specialiserar sig och som utför förundersökningen av människohandelsbrotten. Polisen arbetar på fältet och måste gräva fram fallen och få offren att berätta sina historier. Människohandelsbrott är långa och svåra projekt som tar tid och man ska ha mycket tålamod när man undersöker människohandelsfall. Polisen håller också kontakt med tredje sektorns organisationer. Man skall också finna de poliser som är intresserade av att arbeta med människohandelsbrott. Polisen kan inte göra detta ensam, utan det behövs ett team: poliser, en bra åklagare, en kunnig domare och kontakter till de organisationer som arbetar med att bekämpa människohandel. Det behövs även gränsöverskridande samarbete för att bekämpa människohandel, och idag är det lätt att kontakta poliser i de andra nordiska länderna, som arbetar med att bekämpa människohandel. Eriksson avslutade med att säga: "Vi måste börja satsa på det här. Vi behöver flera människor att arbeta på fältet."

Bild 14: Malene Muusholm, Kenneth Eriksson och Laura Sairanen

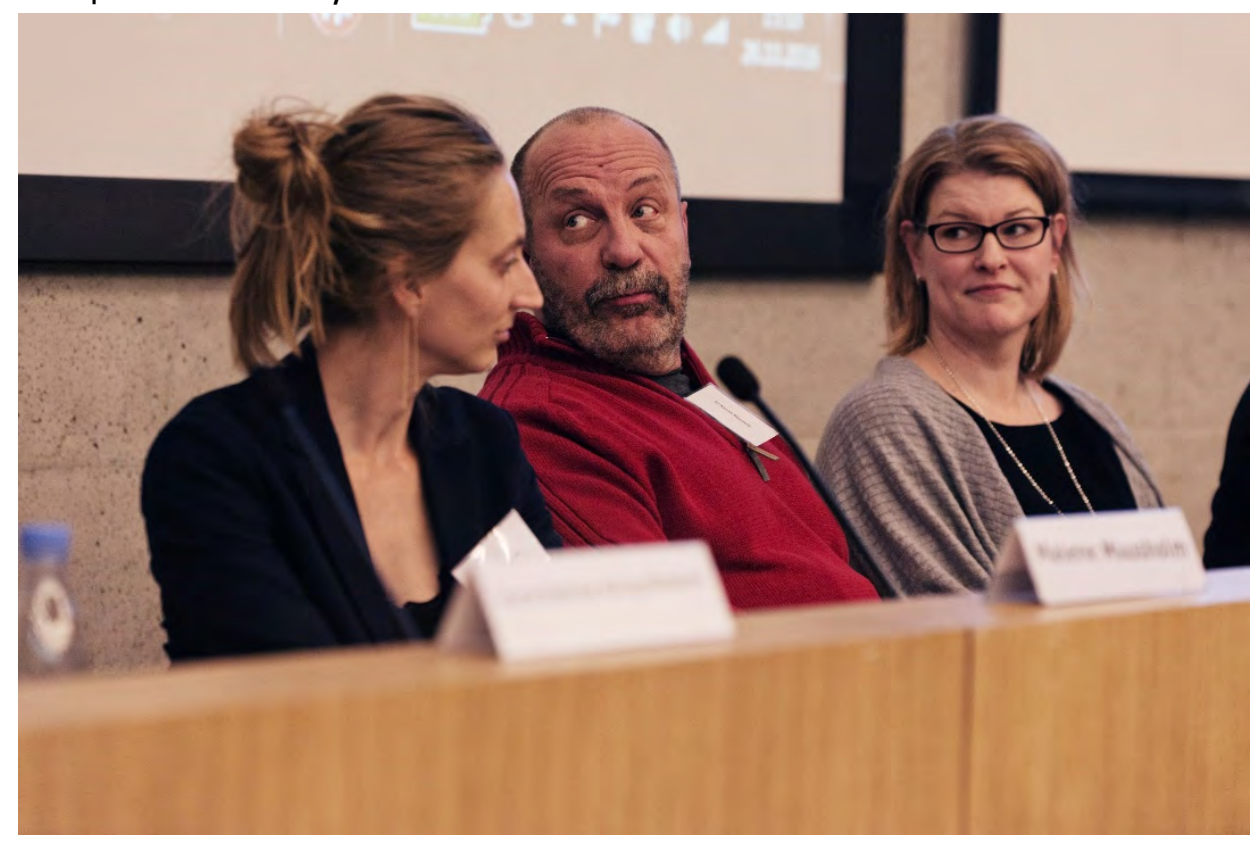

Laura Sairanen, häradsåklagare hos Riksåklagaren i Finland påpekade att om poliser som utreder människohandelsbrott förstår vad människohandel är och att de har satt sig in i det fall som utreds, så är det enklare för en åklagare att föra fallet till en domstol. Sairanen sade att det har förekommit problem med tolkar, som inte har tolkat vad åklagare och poliser säger, utan har också framfört sina egna åsikter till offren. Därför är det oerhört viktigt att ha bra tolkar i rättegångarna. Om domaren för rättegången inte förstår vad människohandel är, så blir det en besvärlig process för åklagaren, som måste förklara allt, och det kan ofta bli fråga stridigheter om alla begrepp.

Thor Martin Elton, politiførstebetjent, Oslo polisdistrikt, Norge sade att idag har polisen i Oslo en specialenhet, som är en del av enheten för organiserad brottslighet, och som enbart arbetar med människohandel. Tidigare var människohandel ett projekt, och 
fick inte samma uppmärksamhet och utredningarna om människohandel hamnade ofta nederst i högen av de brott, som skulle utredas. Elton presenterade ett samarbete med polisen i Stockholm, som handlade om en grupp ficktjuvar, som var på väg med tåget till Oslo. Expertgrupp från polisen i Oslo följde med gruppen och såg att det var två flickor, som utförde snattandet och att det var fullvuxna personer, som följde med flickornas snatteri. Polisen i Stockholm hade ansett att det var märkligt att de 12-åriga flickorna begick brotten. Den norska polisen samlade in bevis med video- och övervakningskameror. Det visade sig att det inte fanns fingeravtryck på flickorna, eftersom Sverige inte tar fingeravtryck på barn under 15 år. Det betydde att man inte hade uppgifter om flickorna hade tagits av polisen i andra nordiska eller europeiska länder. Den norska polisen fick uppgifter om att gruppen hade varit aktiv i många europeiska länder. Det kom även fram att en del av gruppen hade skickats upp till de nordiska länderna för att undersöka hur myndigheterna agerar i situationer som denna. Elton påpekade, att det är oerhört viktigt att polisen i fall som detta, på ett enkelt sätt kan direkt ta kontakt med poliser i andra nordiska länder. Han sade att det är problematiskt, att fingeravtryck inte alltid tas på minderåriga, och att det överlag är problem med registrering av brott, där barn utnyttjas att utföra kriminella handlingar. Ifall brott inte registreras, blir det extra svårt att utreda denna typ av fall, speciellt om offren inte vill samarbeta. En utmaning med dessa barnoffer är att de ofta har starka band till sin förövare. Det är ofta så att förövaren är den enda vuxna personen i barnens liv.

\section{Bild 15: Thor Martin Elton}

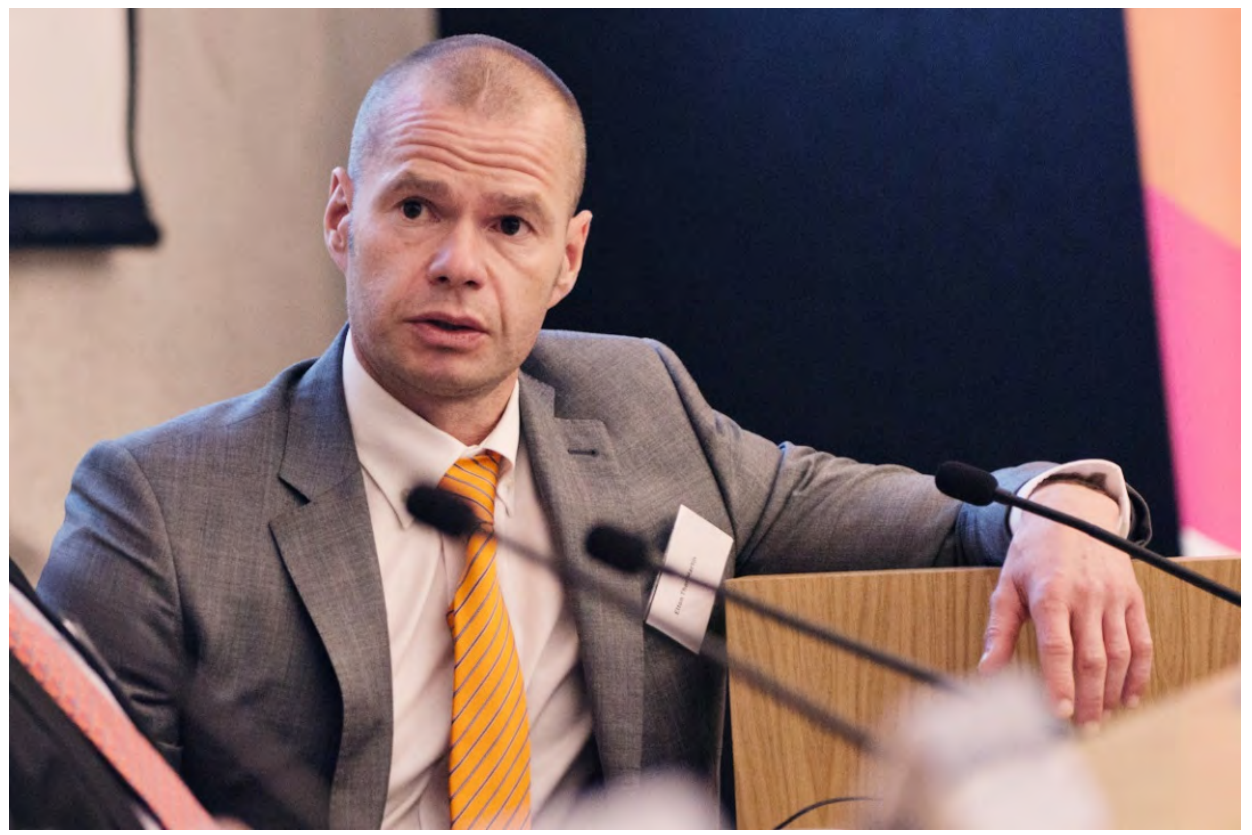

Helena Ljunggren, kammaråklagare från Internationella åklagarkammaren Malmö i Sverige, sade att det i Malmö finns engagerade utredare som förstår vilken brottslighet människohandel är och som förstår lagstiftningen. Det finns också spanare inom polisen som förstår vad det handlar om och som kan fånga upp information under sina 
spaningar. Ljunggren poängterade också att det behövs tålamod för att samla in bevis om människohandelsbrott. Det finns många bra advokater, som biträder offren vid rättegångar och som engagerar sig i brottsoffret. Advokaterna ska vara ett bra stöd för offret och vara med offret från första polisförhöret. Advokaten ska hjälpa till med att offret får tillit till de poliser och åklagare, som arbetar med fallet, och hjälpa med att offret förstår varför det är viktigt att de berättar sin historia. De brottsoffer, som har valt att återvända till sina hemländer, måste förhöras i sina hemländer, och då har det varit bra att advokater från Sverige har följt med, för att biträda människohandelsoffren under förhören. Ljunggren berättade att det hon har saknat i sitt arbete som åklagare för människohandelsbrott är att hon inte har fătt kontakt med kollegor i andra länder, på samma sätt som hon har haft när hon arbetat med narkotikafall och människosmugglingsbrott. Eftersom man i Sverige inte är nöjd med resultatet $i$ människohandelsbrott, så drar man sig för att ge resurser till utredningar av människohandelsbrott, eftersom man inte är övertygad om det lyckas att utreda brotten.

\section{Bild 16: Helena Ljunggren}

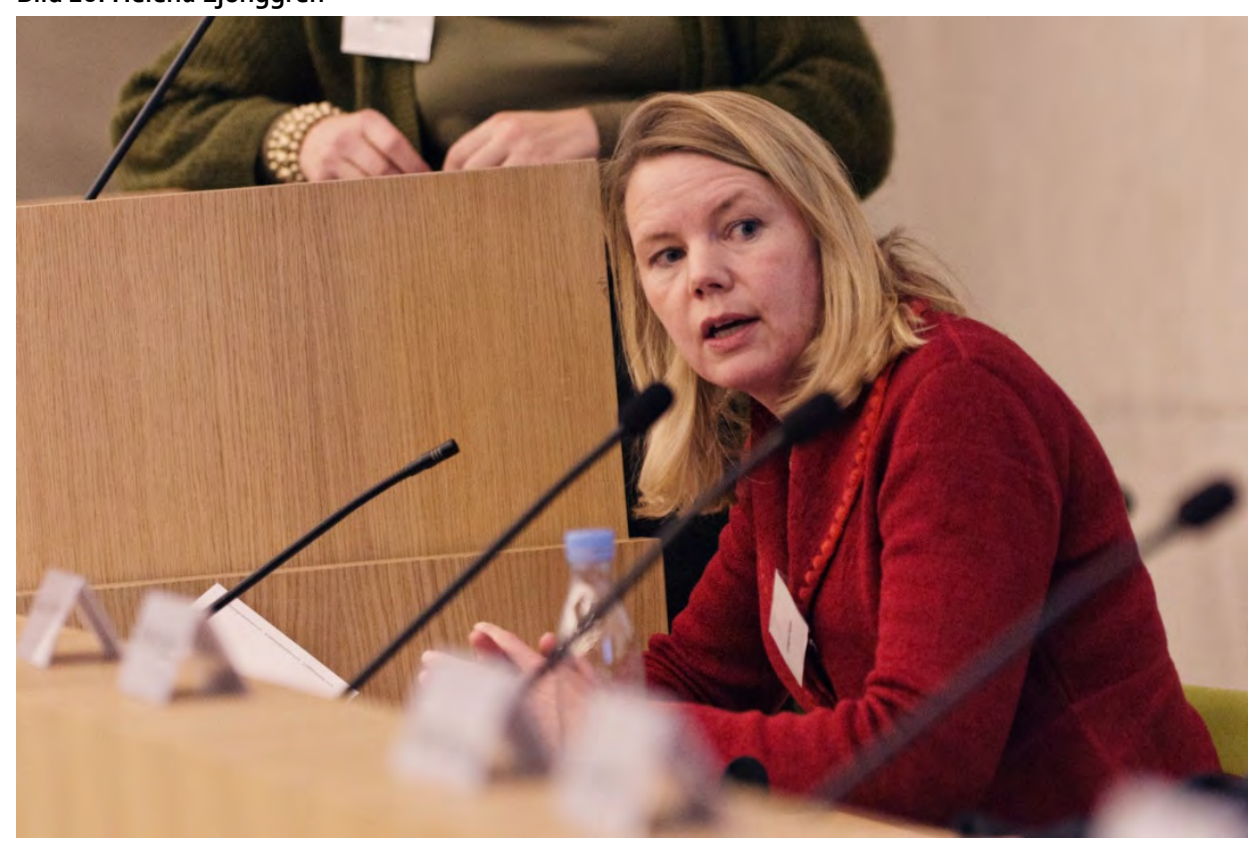

\subsection{Sammanställning av paneldebatten}

Eva Biaudet konstaterade att utmaningarna idag för att utreda människohandel i alla de nordiska länderna är att utredningar tilldelas små resurser, vilket leder till att utredningar av människohandelsbrott inte prioriteras och det resulterar i att det inte inom polisen byggs upp den specialkunskap och kompetens som behövs för att effektivt utreda människohandelsbrott. Människohandel är ett komplicerat område, och därför behövs det experter med specialkompetens hos alla myndigheter, som blir 
involverade i fall om människohandel, från polis, åklagare och domare till hjälpsystem för offren och social- och hälsosektorn samt hos medborgarorganisationer.

Panelen konstaterade att de nordiska länderna är små länder och har nytta av att samarbeta med varandra, speciellt eftersom de nordiska länderna till strukturen är lika så utnyttjar också människohandlarna samma metoder i hela Norden. Det nordiska samarbetet kunde ske genom årliga expertmöten för dem som dagligen arbetar med att bekämpa människohandel. Nordiska politiker har för lite kunskap om människohandel och borde involveras mer i dessa frågeställningar och konferenser som arrangeras i Norden. Det behövs mera kunskap om människohandel i olika perspektiv, speciellt inom polis och rättsväsendet, men också inom andra myndigheter och organisationer, som arbetar med att bekämpa människohandel och hos experter som kommer i kontakt med människor, som är offer för olika former av människohandel.

Bild 17: Konferensen Norden som en gemensam marknad för människohandel

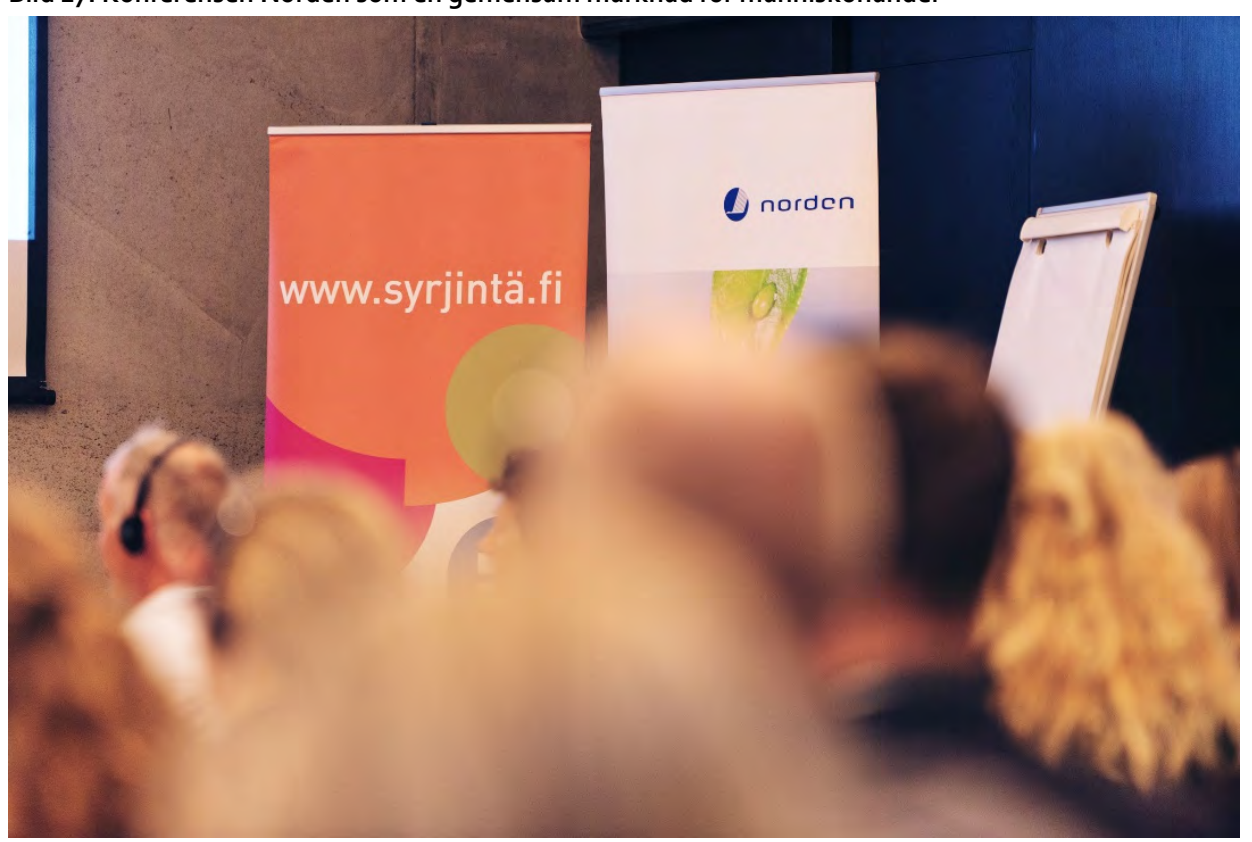





\section{Sammandrag}

Människohandel är vår dags moderna slaveri och ger alla myndigheter, organisationer, experter och frivilliga i Norden utmaningar i att bekämpa människohandel. Människohandlarna och de kriminella utvecklar hela tiden nya metoder och är på det sätt flera steg före eftersom lagstiftningen och rättsväsendet inte har möjlighet att uppdatera sina metoder i insatserna mot människohandel. Detta leder till att poliser och åklagare inte alltid har tillräckliga verktyg att arbeta med att bekämpa de nyaste trenderna inom människohandel. Idag ser vi i Norden nya trender som utnyttjande av fattiga människor i bidragsfusk och människohandlare, som tvingar kvinnor och män, flickor och pojkar att utföra kriminella handlingar, som resulterar i att polis och åklagare inte alltid kan skilja på vem som är kriminell och vem som är offer för människohandel. Personer tvingas också att arbeta utan ersättning, i rengörings- och byggnadsbranschen, på restauranger, i lantbruk, som bärplockare och tiggare. Barn utnyttjas sexuellt via internet $i$ ett land, och i olika länder runt om i världen kan förövarna online delta till utnyttjandet, genom att de ger order om hur utnyttjandet ska ske, i enlighet med deras egna sexuella preferenser. Detta leder till rättsliga utmaningar när brottet sker i många länder samtidigt, eftersom kriminaliteten är gränslös, medan straffsystemen är nationella. Den fråga som då uppstår är: Var ska brottet behandlas?

Användningen av expertvittnen under rättegångarna för att förstå hur förövarna får makt över sina offer blir allt viktigare för att domstolen skall förstå den situation som offren för människohandel hamnar i. Människohandlarna använder sig av utpressning för att få offren att fortsätta att arbeta för dem. Offer för sexuellt utnyttjande blir filmade då de säljer sex till kunder. Offer kan även hotas med att människohandlarna kommer att skada t.o.m ta livet av deras barn och/eller föräldrar, som bor kvar i deras hemland. Detta resulterar ofta i att offren inte vågar ställa upp som vittnen i rättegångssalen och då blir det svårt för åklagare och polis att få tillräckliga bevis om människohandelsbrotten. Det poängterades flera gånger att det är viktigt att få offren att berätta sin historia, för offrets berättelse är oftast det starkaste beviset för att offret har blivit utnyttjat i människohandel. Detta betyder att domstolarna ska införa nya metoder, så att offren kan vittna i rätten utan att de behöver konfronteras med de kriminella som utnyttjat dem.

Barn som offer för människohandel är mycket sårbara. Det har varit svårt att identifiera barn som offer för människohandel och många barn försvinner och myndigheterna vet inte vart de har tagit vägen. Under hösten 2015 med den stora flyktingströmmen kom många barn till de nordiska länderna ensamma eller tillsammans med fullvuxna som inte var barnens släktingar. Barnen berättar inte om att de blir utnyttjade och de fullvuxna de reser med kan vara den enda fullvuxenkontakt som de har, vilket gör att de inte vågar berätta att de blir utnyttjade. 
Under konferensen diskuterades även hur kvinnor och män blir behandlade av människohandlarna. De flesta offer för människohandel för prostitution och sexuellt utnyttjande i Europa idag är kvinnor, de utgör $69 \%$ av alla identifierade offer. Män utnyttjas i olika former för tvångsarbete och männen uppfattar sällan sig som offer för människohandel. Idag är de flesta hjälpsystem för offren uppbyggda efter de behov för kvinnor som utnyttjats sexuellt i prostitution. I de nordiska länderna har man idag en större förståelse för att kvinnor och män, som offer behöver olika former av hjälp, och hjälpsystemen utvecklas för att möta offrens behov och ge dem stöd och hjälp så att de ska kunna skapa sig ett nytt liv.

Paneldebattens konklusion var att nordiskt samarbete $\mathrm{i}$ insatsen mot människohandel behövs för att utbyta av erfarenheter och kunskap om metoder att bekämpa alla former av människohandel. Eftersom det idag i de enskilda nordiska länderna inte finns så många rättsfall om människohandel är det viktigt att polis, åklagare och också domare, som arbetar med människohandelsbrott, på nordiska konferenser kan utbyta erfarenheter och diskutera människohandel i ett brett perspektiv om allt från de kriminellas agerande, polisutredningar, rättegångar till hjälpsystem för offer. Det poängterades även, att det är viktigt att diskutera människohandel i offentligheten för att sprida information, så att människor lär sig att identifiera människohandel också i sina närmiljöer. 


\section{Summary}

The conference on The Nordic Countries - a Common Market for Human Trafficking took place on 26 October 2017 in Helsinki, Finland.

The challenges shared by the Nordic countries in fighting human trafficking were the subject of discussion during the conference. The aim was to exchange experiences on new trends in human trafficking; children as victims of human trafficking; legal processes, from the identification of the victims to decisions handed down by courts; and identification of and help for victims. A gender perspective was integrated into the conference program, and all speakers were given the task of reflecting in their presentations on how human trafficking affects women and men, and girls and boys.

In newer forms of human trafficking, women and men, and girls and boys are exploited by being forced to carry out criminal acts, work in certain sectors as construction, restaurants and cleaning and sell sexual services. Human traffickers lure individuals with promises of work and housing, inducing them to travel to the Nordic countries and other parts of Europe. The traffickers also use victims' identification documents for benefits fraud within the Nordic welfare systems. The victims are often not aware of being used in criminal actions.

One of the challenges in combating human trafficking in the Nordic countries presently is that traffickers regard the Nordic region as a common market and send victims from one country to another. This poses major challenges for criminal investigators, as legislation itself is national while the crimes transcend borders, as the same traffickers operate simultaneously in different Nordic countries. There is now a heightened need for cooperation between authorities and organisations in order to step up measures against human trafficking crimes.

The conference used as its starting point the various results and experiences obtained from joint-Nordic initiatives by the Nordic Council of Ministers and organizations throughout the Nordic countries. A wealth of knowledge in the form of national reports, analyses, recommendations and measures for combating human trafficking is available for use.

The conference discussions focused on three themes:

1. Children as victims of human trafficking..

2. Challenges in the legal process

3. Women and men as victims of human trafficking.

The conference concluded with a panel discussion titled How can the Nordic countries cooperate on actions against human trafficking?

The conference discussions also addressed the following issues: 
- What new forms of human trafficking are occurring in the Nordic countries and Europe?

- What challenges do police and prosecutors face today in investigating different forms of human trafficking?

- How are child victims of human trafficking exploited and how are the cases handled?

- How are women and men exploited differently as victims of human trafficking?

- Why is human trafficking for sexual exploitation a gender equality issue?

- What methods do perpetrators use to gain power over their victims?

- Which are the psychological consequences of human trafficking?

- What are the best ways to exchange experiences, working methods and knowledge?

- What are the best practical ways to cooperate in border-crossing investigations?

- What can be achieved within the framework of Nordic cooperation?

The conference gathered 160 participants from all of the Nordic countries. In total, 43 $\%$ of participants were representatives of police and the judiciary; of them, 37 were police officers and 32 were prosecutors, judges and attorneys. Other participants included civil servants, various experts, researchers and representatives of non-governmental organisations.

The conference was organized by the Non-Discrimination Ombudsman in Finland - also the National Rapporteur for Trafficking in Human Beings for Finland - in cooperation with the Finnish chairmanship of the Nordic Council of Ministers. The conference was financed by the Council of Ministers for Gender Equality (MR-JÄM), Council of Ministers for Legislative Affairs (MR-LAG) and the Nordic Committee for Children and Young People (NORDBUK).

The conference presentations from The Nordic Countries - a Common Market for Human Trafficking are available at:

- https://www.syrjinta.fi/sv/web/sv/-/nordisk-konferens-norden-som-gemensammarknad-for-manniskohandel 
Nordiska ministerrådet

Nordens Hus

Ved Stranden 18

DK-1061 Köpenhamn K

www.norden.org

\section{Norden som en gemensam marknad för människohandel}

Nya former inom människohandel utnyttjar kvinnor och män, flickor och pojkar genom att tvinga dem till att utföra kriminella handlingar, arbeta och sälja sexuella tjänster. Människohandlarna lockar offer till Norden med löften om arbete och använder offrens identiteter för bidragsfusk genom att utnyttja de nordiska ländernas välfärdssystem.

En utmaning i bekämpning av människohandel i Norden är att människohandlarna ser Norden som en gemensam marknad.

Det ger stora utmaningar för brottsutredarna eftersom lagstiftningen är nationell och brotten är gränsöverskridande, när samma människohandlare opererar samtidigt i de olika nordiska länderna. Konferensen visade att det finns ett ökat behov för samarbete för att effektivera insatserna och brottsbekämpningen mot människohandeln.

Konferensen diskuterade barn, kvinnor och män som offer för människohandel och utmaningar i rättsprocesser. 